This item is the archived peer-reviewed author-version of:

Novel amino-pyrazole ureas with potent in vitro and in vivo antileishmanial activity

\title{
Reference:
}

Mowbray Charles E., Braillard Stéphanie, Speed William, Matheeussen An, Maes Louis, et al..- Novel amino-pyrazole ureas with potent in vitro and in vivo antileishmanial activity

Journal of medicinal chemistry - ISSN 0022-2623 - 58:24(2015), p. 9615-9624

Full text (Publishers DOI): http://dx.doi.org/doi:10.1021/ACS.JMEDCHEM.5B01456

To cite this reference: http://hdl.handle.net/10067/1292190151162165141 
Journal of

Medicinal Chemistry

Subscriber access provided by UNIV ANTWERPEN

Article

\section{Novel Amino-pyrazole Ureas with Potent In \\ Vitro and In Vivo Antileishmanial Activity}

Charles E. Mowbray, Stéphanie Braillard, William Speed, Paul Alan Glossop, Gavin A.

Whitlock, Karl R Gibson, James EJ Mills, Alan Daniel Brown, J. Mark F. Gardner, Yafeng

Cao, Wen Hua, Garreth L Morgans, Pim-Bart Feijens, An Matheeussen, and Louis J Maes

J. Med. Chem., Just Accepted Manuscript • DOI: 10.1021/acs.jmedchem.5b01456 • Publication Date (Web): 16 Nov 2015

Downloaded from http://pubs.acs.org on December 1, 2015

\section{Just Accepted}

"Just Accepted" manuscripts have been peer-reviewed and accepted for publication. They are posted online prior to technical editing, formatting for publication and author proofing. The American Chemical Society provides "Just Accepted" as a free service to the research community to expedite the dissemination of scientific material as soon as possible after acceptance. "Just Accepted" manuscripts appear in full in PDF format accompanied by an HTML abstract. "Just Accepted" manuscripts have been fully peer reviewed, but should not be considered the official version of record. They are accessible to all readers and citable by the Digital Object Identifier (DOI®). "Just Accepted" is an optional service offered to authors. Therefore, the "Just Accepted" Web site may not include all articles that will be published in the journal. After a manuscript is technically edited and formatted, it will be removed from the "Just Accepted" Web site and published as an ASAP article. Note that technical editing may introduce minor changes to the manuscript text and/or graphics which could affect content, and all legal disclaimers and ethical guidelines that apply to the journal pertain. ACS cannot be held responsible for errors or consequences arising from the use of information contained in these "Just Accepted" manuscripts. 


\section{Novel Amino-pyrazole Ureas with Potent In Vitro and In Vivo Antileishmanial Activity.}

Charles E. Mowbray, ${ }^{* \dagger}$ Stéphanie Braillard, ${ }^{\dagger}$ William Speed, ${ }^{\dagger}$ Paul A. Glossop, ${ }^{\mathbf{\Lambda}, \grave{t}}$ Gavin A.

Whitlock, ${ }^{\ddagger}$ Karl R. Gibson, ${ }^{+}$James E. J. Mills, ${ }^{\ddagger}$ Alan D. Brown, ${ }^{\S}$ J. Mark F. Gardner, ${ }^{\|}$Yafeng Cao, $\stackrel{\Perp}{\Perp}$ Wen Hua,$\stackrel{\Perp}{\Perp}$ Garreth L. Morgans, ${ }^{\overline{\mathrm{T}}, \Delta}$ Pim-Bart Feijens, ${ }^{\#}$ An Matheeussen, ${ }^{\#}$ and Louis J. Maes"

${ }^{\dagger}$ Drugs for Neglected Diseases initiative (DNDi), 15 Chemin Louis-Dunant, 1202 Geneva, Switzerland.

${ }^{\ddagger}$ Sandexis Medicinal Chemistry Ltd, Innovation House, Discovery Park, Ramsgate Road, Sandwich, Kent, CT13 9ND, UK.

${ }^{\S}$ Pfizer Worldwide Medicinal Chemistry, The Portway Building, Granta Park, Great Abington, Cambridge, CB21 6GS, UK.

"AMG Consultants Ltd, Discovery Park House, Discovery Park, Ramsgate Road, Sandwich, Kent, CT13 9ND, UK.

${ }^{\Perp}$ WuXi AppTec (Wuhan) Co. Ltd., 666 Gaoxin Road, East Lake High-Tech Development Zone, Wuhan 430075, China P. R. 


\author{
$\bar{\pi}_{i}$ Themba Pharmaceuticals, Building T5, Pinelands Site, High Street, Modderfontein 1609, \\ Gauteng, SA. \\ ${ }^{\#}$ Laboratory for Microbiology, Parasitology and Hygiene (LMPH), University of Antwerp, S7, \\ Universiteitsplein 1, 2610 Wilrijk, Antwerp, Belgium.
}

KEYWORDS Visceral leishmaniasis, L. infantum, L. donovani, antileishmanial, antiparasitic, amino-pyrazole, pyrazole, urea.

\begin{abstract}
Visceral leishmaniasis is a severe parasitic disease that is one of the most neglected tropical diseases. Treatment options are limited and there is an urgent need for new therapeutic agents. Following an HTS campaign and hit optimization, a novel series of amino-pyrazole ureas has been identified with potent in vitro antileishmanial activity. Furthermore, compound 26 shows high levels of in vivo efficacy $(>90 \%)$ against Leishmania infantum, thus demonstrating proof of concept for this series.
\end{abstract}

\title{
INTRODUCTION
}

Visceral leishmaniasis (VL) is a systemic disease caused by the protozoan parasites Leishmania donovani and L. infantum. ${ }^{1,2}$ The parasites (promastigotes) are transmitted through the bite of female phlebotomine sand flies; in the human host, intracellular parasites (amastigotes) target the reticuloendothelial system, surviving and multiplying in different macrophage populations. ${ }^{1-4}$ VL occurs in Asia, East Africa, Latin America, the Mediterranean Basin and the Middle East; ${ }^{1}$ 
$90 \%$ of global cases occur in just six countries: Bangladesh, Brazil, Ethiopia, India, South Sudan and Sudan. ${ }^{5}$ It is estimated that there are $0.2-0.4$ million new cases of VL per year and a case fatality of $>20,000$ per year. ${ }^{5}$ Most infections are asymptomatic but in patients who develop symptoms, initial presentation is insidious, with development of splenomegaly, hepatomegaly, fever, anaemia, pancytopaenia, weight loss and weakness occurring progressively over a period of weeks or even months; VL can be fatal if left untreated. ${ }^{1,4,5}$ Despite this, VL is one of the most neglected tropical diseases (NTD). ${ }^{1-3}$

Current treatment options for patients with VL include sodium stibogluconate (SSG; antimonial therapy), liposomal amphotericin B (LAB; polyene antibiotic), paromomycin (PM; aminoglycoside antibiotic) and miltefosine (phospholipid). ${ }^{1-4}$ All these drugs have deficiencies in terms of safety, efficacy, ease-of-use, cost or drug resistance. ${ }^{1-4}$ For example, SSG, LAB and PM are all delivered by long-duration, intravenous infusions or intramuscular injections; only miltefosine is an oral drug, and all are associated with adverse events or toxicity. ${ }^{1,3,4}$ Research and development for the treatment of VL has evolved in recent years, including the discovery of two nitroimidazole drugs, fexinidazole (Phase II) and (2R)-2-methyl-6-nitro-2-\{[4(trifluoromethoxy)phenoxy]methyl $\}-2 H, 3 H$-imidazo[2,1-b][1,3]oxazole (VL-2098, preclinical), from the Drugs for Neglected Diseases initiative (DNDi). ${ }^{6-11}$ The DNDi has also recently published the discovery of two new series of antileishmanial compounds: 2-substituted quinolines with potent in vitro activity and promising in vivo efficacy against VL, ${ }^{12,13}$ and aminothiazoles with excellent in vitro potency and good physicochemical properties. ${ }^{14}$ Current research towards VL is intensive, as judged by the volume and frequency of medicinal chemistry publications and the extent of a recent in-depth review. ${ }^{2}$ Many research groups have reported new chemical scaffolds with promising activity against VL and potential for the future 
development of antileishmanial agents. ${ }^{15-21}$ Furthermore, a significant number of recent publications have emerged from research groups in India and Brazil, highlighting the urgency with which new medicines are being sought in countries where VL is most prevalent. ${ }^{1,12-14,22-28}$ Overall, however, many of the newly-published scaffolds contain undesirable structural alerts associated with adverse toxicity findings. ${ }^{29}$ Of note, several pyrazole-based series of antileishmanial compounds have been reported by research groups in Brazil, but these generally have modest-weak activity against Leishmania species (e.g. L. amazonensis) that cause cutaneous leishmaniasis (CL), not VL. ${ }^{1,28,30-35}$ Consequently, there is an urgent need for additional research into more effective therapeutic options for the treatment of VL. ${ }^{1-4}$

The overall goal of this project is to deliver a short-course oral treatment for VL that meets the published target product profile (TPP) to address the significant deficiencies of current standardof-care medications. ${ }^{3,36}$ In this preliminary disclosure, we report the discovery of a novel series of pyrazole-based antileishmanial compounds with excellent in vitro potency against $L$.

infantum. In addition, examples from this series show equivalent in vitro potency against $L$. donovani and high levels of in vivo efficacy ( $>90 \%$ ) against L. infantum in a hamster model of VL. Compounds from the series also demonstrate promising in vivo pharmacokinetics and metabolic stability in human microsomes. Consequently, this series has the potential to deliver a breakthrough in the search for safe and effective oral agents for the treatment of VL.

\section{RESULTS AND DISCUSSION}

Chemistry. The synthesis of amino-pyrazole intermediates was straightforward (Scheme 1). Commercially available 3-(pyridin-2-yl)-1H-pyrazol-5-amine was chlorinated with NCS to provide chloro-substituted amino pyrazole 1. Methyl picolinate was treated with lithiated 
cyclopropylacetonitrile to give cyano ketone 2 , which was cyclized with hydrazine to provide cyclopropyl-substituted amino pyrazole 3. Final compounds were synthesized from 3-(pyridin-2yl)-1H-pyrazol-5-amine, chloro-derivative 1 or cyclopropyl-derivative $\mathbf{3}$, according to one of two general methods. Amides 4-10 were synthesized using the required amino-pyrazole intermediate and corresponding acid chloride, according to Method A (Scheme 2). Ureas 14-26 were synthesized from the required amino-pyrazole intermediates, via their phenyl carbamates 11-13 (synthesized using Method B) and corresponding amine, according to Method C (Scheme 3).

Scheme 1. Synthesis of aminopyrazole intermediates. ${ }^{\text {a }}$

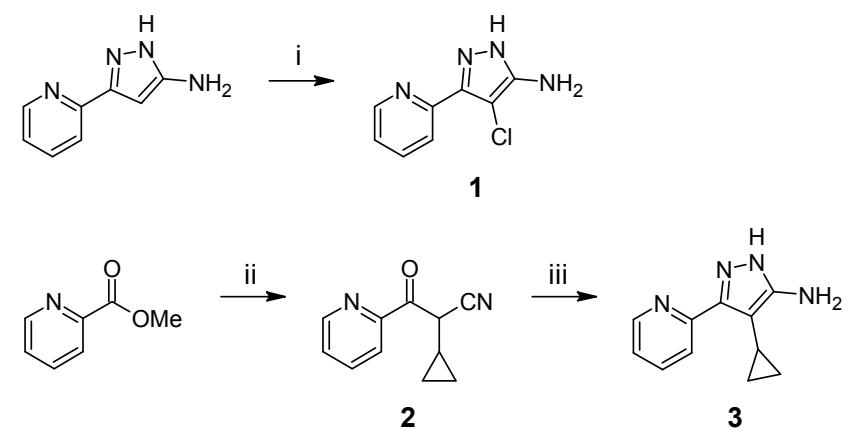

${ }^{\mathrm{a}}$ Reagents and conditions: (i) NCS, DMF, $0{ }^{\circ} \mathrm{C}, 0.5 \mathrm{~h}$; (ii) 2-cyclopropylacetonitrile, LDA, dry $\mathrm{THF},-78{ }^{\circ} \mathrm{C}$ to rt, $18 \mathrm{~h}$; (iii) hydrazine hydrate, EtOH, reflux, $16 \mathrm{~h}$.

Scheme 2. General synthesis of amides $\mathbf{4 - 1 0}$. $^{\text {a }}$

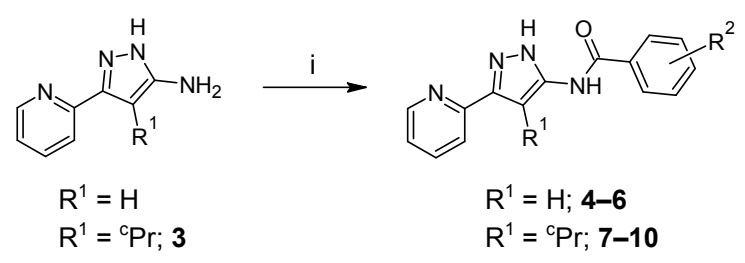

${ }^{a}$ Reagents and conditions: (i) Method A: corresponding acyl chloride, MeCN, rt to reflux, $16 \mathrm{~h}$. 
Scheme 3. General synthesis of ureas 14-26. ${ }^{\text {a }}$

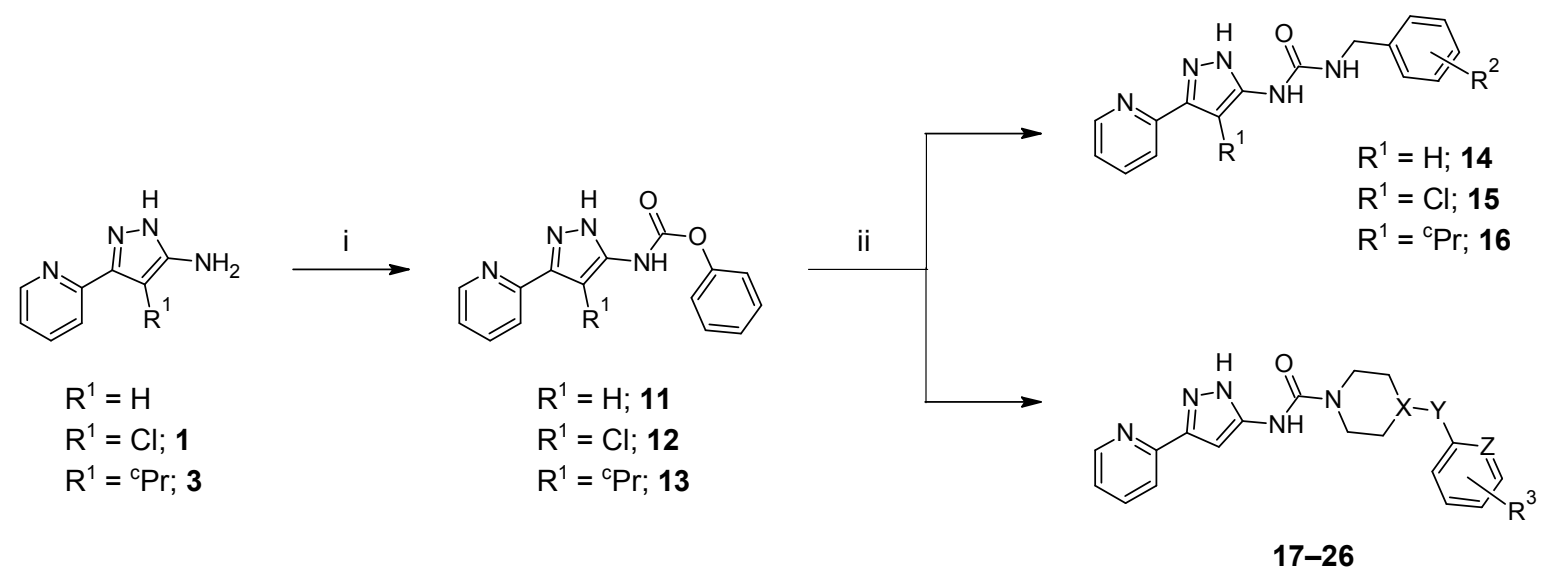

\footnotetext{
${ }^{\mathrm{a}}$ Reagents and conditions: (i) Method B: phenyl chloroformate, pyridine, $0{ }^{\circ} \mathrm{C}$ to $\mathrm{rt}, 12.5 \mathrm{~h}$; (ii) Method C: corresponding amine, triethylamine, chloroform, reflux, $16 \mathrm{~h}$.
}

This pyrazole series was initially identified from an HTS campaign with approximately 95,000 compounds from a diverse subset, selected to represent the broad chemical space of Pfizer's small-molecule compound collection. ${ }^{37}$ Compound 4 was a moderately potent hit $\left(\mathrm{IC}_{50}=10 \mu \mathrm{M}\right)$ with in vitro activity against $L$. donovani amastigotes in THP-1 cells (human monocytic leukaemia cells). The primary HTS assay employed this intracellular assay, but some early characterisation of the hit and initial analogues also showed activity (e.g. 4; $\mathrm{IC}_{50} \geq 10.9 \mu \mathrm{M}$ ) against axenic L. donovani amastigotes (Table 1). Initial simplification of the structure led to additional hit compounds 5 and $\mathbf{6}$ with improved potency $\left(\mathrm{IC}_{50}=3.71 \mu \mathrm{M}\right.$ and $0.738 \mu \mathrm{M}$, respectively) against axenic L. donovani amastigotes. However, 4-6 only showed weak activity $\left(\mathrm{IC}_{50}>40 \mu \mathrm{M}\right)$ when tested in an in vitro macrophage assay using intracellular L. infantum 
amastigotes (Table 1); nor was there any evidence of cytotoxicity $\left(\mathrm{CC}_{50}>40 \mu \mathrm{M}\right)$ towards the host cell, primary mouse macrophages (PMM). In contrast, the clinical agent miltefosine, used as a reference drug, demonstrated good activity $\left(\mathrm{IC}_{50}=7.26 \mu \mathrm{M}\right)$ in this in vitro macrophage assay.

Table 1. Structure and antileishmanial activity of hits 4-6.

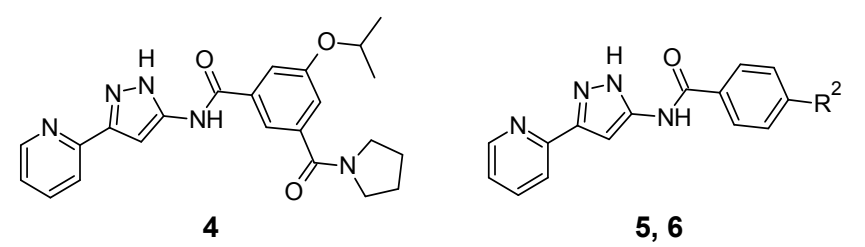

\begin{tabular}{|l|l|l|l|l|}
\hline Compound & $\mathrm{R}^{2}$ & $\begin{array}{l}\text { Axenic } L . \\
\text { donovani } \\
\text { amastigote } \\
\mathrm{IC}_{50}(\mu \mathrm{M})^{\mathrm{a}}\end{array}$ & $\begin{array}{l}\text { Intramacrophage } \\
\text { L. infantum } \\
\text { amastigote } \\
\mathrm{IC}_{50}(\mu \mathrm{M})^{\mathrm{b}}\end{array}$ & $\begin{array}{l}\mathrm{PMM}^{\mathrm{b}} \\
\mathrm{CC}_{50} \\
(\mu \mathrm{M})\end{array}$ \\
\hline $\mathbf{4}$ & - & $\geq 10.9$ & $>42.4$ & $>40.3$ \\
\hline $\mathbf{5}$ & $\mathrm{Cl}$ & 3.71 & $>64^{\mathrm{c}}$ & $>64^{\mathrm{c}}$ \\
\hline $\mathbf{6}$ & $\mathrm{OMe}$ & 0.738 & $>40.3$ & $>40.3$ \\
\hline Miltefosine & - & n.d. & 7.26 & 33.1 \\
\hline
\end{tabular}

${ }^{a}$ Geometric-mean value of at least three independent tests. ${ }^{b}$ Geometric-mean value of at least three independent tests in primary mouse macrophages (PMM). 'Single test value $(n=1)$. n.d., not determined.

Although axenic amastigotes have been used for HTS (resulting in the identification of some starting points), occasional poor translation of activity from axenic to intracellular amastigotes has been reported. ${ }^{3}$ The axenic amastigote assay has advantages in terms of speed and cost, but the resource-intensive intracellular amastigote assay is thought to be the most relevant as the 
parasite survives and divides in macrophages to cause the actual disease. ${ }^{2}$ Consequently, additional compounds were designed, synthesized and tested in the intracellular L. infantum amastigote assay to establish whether this scaffold represented a genuinely potent series (comparable to miltefosine) worthy of lead optimization. Initial exploration of the right-hand side of the molecule did not identify any alternative amide groups or substituents with the desired potency against intracellular amastigotes.

However, subsequent investigation of the pyrazole core did result in compounds with muchimproved potency. In particular, addition of a cyclopropyl group at the 4-position of the pyrazole ring provided $7\left(\mathrm{IC}_{50}=2.02 \mu \mathrm{M}\right)($ Table 2$)$, which was significantly more potent than $\mathbf{6}$, its unsubstituted counterpart. Furthermore, 7 also demonstrated similar antileishmanial activity against $L$. donovani $\left(\mathrm{IC}_{50}=2.63 \mu \mathrm{M}\right)$. The encouraging potency of 7 prompted us to re-examine a variety of benzamide substituents with this new core, especially as we envisaged that the cyclopropyl group would sterically hinder the amide moiety and increase the likelihood of identifying metabolically-stable compounds. Excellent potency was observed with 2-methoxy benzamide $8\left(\mathrm{IC}_{50}=0.064 \mu \mathrm{M}\right)$. A variety of other benzamides showed similar levels of potency to 7, for example the 2-fluoro $\left(\mathbf{9} ; \mathrm{IC}_{50}=0.965 \mu \mathrm{M}\right)$ and 2,6-dichloro $\left(\mathbf{1 0} ; \mathrm{IC}_{50}=2.11 \mu \mathrm{M}\right)$ analogues (Table 2). Importantly, compounds 7-10 showed no evidence of cytotoxicity $\left(\mathrm{CC}_{50}\right.$ $>51 \mu \mathrm{M})$ in the counter-screen using the same PMM as those used in the intracellular amastigote assay (Table 2). In addition, encouraging stability (e.g. 7; $\mathrm{Cl}_{\text {int }}=12.75 \mu \mathrm{L} / \mathrm{min} / \mathrm{mg}$ ) was observed in human liver microsomes (HLM). Compounds 7-10 were significantly more potent than miltefosine, representing a key breakthrough for the series that prompted further hit optimization. 
Table 2. Structure and antileishmanial activity of amides 7-10 and ureas 14-16.

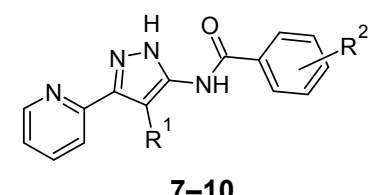

7-10

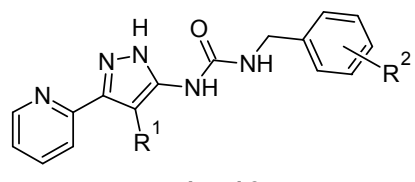

14-16

\begin{tabular}{|l|l|l|l|l|}
\hline Compound & $\mathrm{R}^{1}$ & $\mathrm{R}^{2}$ & $\begin{array}{l}\text { Intramacrophage } \\
\text { L. infantum } \\
\text { amastigote } \\
\mathrm{IC}_{50}(\mu \mathrm{M})^{\mathrm{a}}\end{array}$ & $\begin{array}{l}\mathrm{PMM}^{\mathrm{a}} \\
\mathrm{CC}_{50} \\
(\mu \mathrm{M})\end{array}$ \\
\hline $\mathbf{7}$ & ${ }^{\mathrm{c}} \mathrm{Pr}$ & $4-\mathrm{OMe}$ & 2.02 & $>64$ \\
\hline $\mathbf{8}$ & ${ }^{\mathrm{c}} \mathrm{Pr}$ & $2-\mathrm{OMe}$ & 0.064 & $>51$ \\
\hline $\mathbf{9}$ & ${ }^{\mathrm{c}} \mathrm{Pr}$ & $2-\mathrm{F}$ & 0.965 & $>64$ \\
\hline $\mathbf{1 0}$ & ${ }^{\mathrm{c}} \mathrm{Pr}$ & $2,6-\mathrm{diCl}$ & 2.11 & $>64$ \\
\hline $\mathbf{1 4}$ & $\mathrm{H}$ & $3-\mathrm{Cl}$ & 0.450 & $>64$ \\
\hline $\mathbf{1 5}$ & $\mathrm{Cl}$ & $\mathrm{H}$ & 0.066 & $>64$ \\
\hline $\mathbf{1 6}$ & ${ }^{\mathrm{c}} \mathrm{Pr}$ & $\mathrm{H}$ & 0.130 & $>45$ \\
\hline Miltefosine & - & - & 7.26 & 33.1 \\
\hline
\end{tabular}

${ }^{\mathrm{a}}$ Geometric-mean value of at least two independent tests in PMM.

However, one issue for the series concerned poor metabolic stability in hamster that precluded us from evaluating compounds in the in vivo hamster model of VL, recognised to be the most relevant model of VL as it closely mimics the pathology of the disease in human. ${ }^{3,38}$ Poor amide stability exclusive to hamster plasma (e.g. 7; 0.3\% remaining after $6 \mathrm{~h}$ ) could be overcome with the sterically-hindered 2,6-dichloro analogue 10 (96.9\% remaining after $6 \mathrm{~h}$ ) but despite this, all analogues had poor stability $\left(\mathrm{Cl}_{\text {int }}>100 \mu \mathrm{L} / \mathrm{min} / \mathrm{mg}\right)$ in hamster liver microsomes (HamLM). We concluded that even when sterically-hindered with the bulky cyclopropyl group, the amide 
moiety was likely to be responsible for the high rate of metabolism in hamster and so decided to investigate ureas as a potential, more polar alternative. Initial benzyl urea analogues such as 1416 (Table 2) had excellent, submicromolar potency (e.g. 16; $\mathrm{IC}_{50}=0.130 \mu \mathrm{M}, \mathrm{A} \log \mathrm{P}=3.15$ ) with no evidence of cytotoxicity $\left(\mathrm{CC}_{50}>45 \mu \mathrm{M}\right)$, although high levels of instability in HamLM $\left(\mathrm{Cl}_{\text {int }}>400 \mu \mathrm{L} / \mathrm{min} / \mathrm{mg}\right)$ remained. Interestingly though, and in contrast to the amide sub-series, 14 did show that it was possible to obtain highly-potent $\left(\mathrm{IC}_{50}=0.450 \mu \mathrm{M}\right)$ ureas without a substituent on the pyrazole core. This provided an opportunity to synthesize additional urea analogues with reduced lipophilicity and potential for greater metabolic stability in HamLM $\left(\mathrm{Cl}_{\text {int }}<100 \mu \mathrm{L} / \mathrm{min} / \mathrm{mg}\right)$ that would enable in vivo efficacy studies.

Phenyl piperidine urea $\mathbf{1 7}$ was quickly identified as a lead compound with excellent in vitro potency $\left(\mathrm{IC}_{50}=0.296 \mu \mathrm{M}\right)$, good selectivity index $(\mathrm{SI})$ over cytotoxicity $\left(\mathrm{CC}_{50}>64 \mu \mathrm{M}\right.$; SI >242) and good stability in HLM (Table 3). Furthermore, 17 showed equivalent antileishmanial activity against $L$. donovani $\left(\mathrm{IC}_{50}=0.078 \mu \mathrm{M}\right)$. Compound 17 did not show any instability in hamster plasma $(100 \%$ remaining after $6 \mathrm{~h})$ but instability in HamLM was still high $\left(\mathrm{Cl}_{\text {int }}=216\right.$ $\mu \mathrm{L} / \mathrm{min} / \mathrm{mg}$ ), prompting us to undertake in vitro metabolite identification studies in HLM and HamLM to understand this in more detail. Whilst there was only one metabolite observed in HLM, seven metabolites were observed in HamLM. Overall, these data indicated that the majority of oxidative metabolism in both HLM and HamLM occurred on the right-hand side of the molecule, i.e. the phenyl piperidine. This gave us the impetus to develop a medicinal chemistry design strategy that focused on retention of the pyridyl left-hand side and unsubstituted pyrazole urea, combined with substituted aryl piperidines and piperazines to block metabolism and/or lower lipophilicity. 
In general, analogues 18-26 (which resulted from our design strategy) possessed excellent levels of antileishmanial activity and SI, combined with good metabolic stability in HLM and, importantly, evidence of an improvement in HamLM stability. Substituted piperidines 18-22 possessed excellent-good potency $\left(\mathrm{IC}_{50}=0.224-2.862 \mu \mathrm{M}\right)$ and good HLM stability $\left(\mathrm{Cl}_{\text {int }}=\right.$ 25.3-42.5 $\mu \mathrm{L} / \mathrm{min} / \mathrm{mg}$ ) across an AlogP range of 3-4. Improved stability in HamLM was observed for chlorophenyl analogues $20\left(\mathrm{Cl}_{\text {int }}=43.8 \mu \mathrm{L} / \mathrm{min} / \mathrm{mg}\right)$ and $21\left(\mathrm{Cl}_{\text {int }}=63.5\right.$ $\mu \mathrm{L} / \mathrm{min} / \mathrm{mg})$, and cyanophenyl analogue $22\left(\mathrm{Cl}_{\text {int }}=80.8 \mu \mathrm{L} / \mathrm{min} / \mathrm{mg}\right)$. As 20 and 21 had a higher AlogP (3.82) than 17 (3.15), it appeared that the improvement in metabolic stability was due to these substituents successfully blocking sites of metabolism. However, the choice of substituent seemed to be important as the fluorophenyl analogues $\mathbf{1 8}$ and $\mathbf{1 9}$ had poor stability in HamLM $\left(\mathrm{Cl}_{\text {int }}=272\right.$ and $207 \mu \mathrm{L} / \mathrm{min} / \mathrm{mg}$, respectively $)$ that was similar to 17 , despite having a lower AlogP (3.36) than 20 and 21. Aryl-oxy piperidines 23 and 24 retained excellent antileishmanial activity $\left(\mathrm{IC}_{50}=0.614\right.$ and $0.853 \mu \mathrm{M}$, respectively). Both compounds are more polar than 17 and had improved metabolic stability in HamLM, especially $24\left(\mathrm{Cl}_{\text {int }}=30.8 \mu \mathrm{L} / \mathrm{min} / \mathrm{mg}\right)$, perhaps driven by a combination of lower AlogP (2.43) and addition of the 4-cyano substituent. The most polar compound (25; $\mathrm{A} \log \mathrm{P}=1.94)$ had excellent stability in HLM and moderate stability in $\operatorname{HamLM}\left(\mathrm{Cl}_{\text {int }}=<11.9\right.$ and $67.3 \mu \mathrm{L} / \mathrm{min} / \mathrm{mg}$, respectively $)$, although potency was approximately 5-fold weaker than 23. It is interesting that although 25 was the most stable compound in HLM, it was only the fifth most stable in HamLM, suggesting that different SAR exists for metabolic stability in these two species. Aryl piperazine $\mathbf{2 6}$ demonstrated good potency against both $L$. infantum and L. donovani ( $\mathrm{IC}_{50}=2.37$ and $1.31 \mu \mathrm{M}$, respectively), combined with good stability in $\mathrm{HLM}$ and $\mathrm{HamLM}\left(\mathrm{Cl}_{\mathrm{int}}=30.8\right.$ and $46.5 \mu \mathrm{L} / \mathrm{min} / \mathrm{mg}$, respectively $)$. The pairwise comparison of $18(\mathrm{~A} \log \mathrm{P}=3.36)$ and $26(\mathrm{~A} \log \mathrm{P}=2.78)$ shows that piperazine is a suitable, more polar 
alternative to piperidine that is able to significantly improve HamLM stability. This may be due to the presence of the extra piperazine nitrogen atom, which could block a site of oxidative metabolism that is specific to hamster (HamLM).

Table 3. Structure, antileishmanial activity, cytotoxicity, SI, HLM/HamLM stability and AlogP for ureas 17-26.

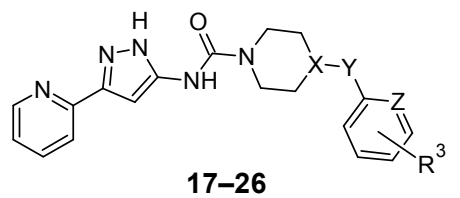

\begin{tabular}{|c|c|c|c|c|c|c|c|c|c|c|c|}
\hline \multirow[t]{2}{*}{ Compound } & \multirow[t]{2}{*}{$\mathrm{X}$} & \multirow[t]{2}{*}{$\mathrm{Y}$} & \multirow[t]{2}{*}{$\mathrm{Z}$} & \multirow[t]{2}{*}{$\mathrm{R}^{3}$} & \multirow{2}{*}{$\begin{array}{l}\text { Intramacrophage } \\
L . \text { infantum } \\
\text { amastigote } \\
\mathrm{IC}_{50}(\mu \mathrm{M})^{\mathrm{a}}\end{array}$} & \multirow{2}{*}{$\begin{array}{l}\mathrm{PMM}^{\mathrm{a}} \\
\mathrm{CC}_{50} \\
(\mu \mathrm{M})\end{array}$} & \multicolumn{2}{|c|}{ MRC5 $^{b}$} & HLM & HamLM & \multirow[t]{2}{*}{$\mathrm{A} \log \mathrm{P}^{39}$} \\
\hline & & & & & & & $\begin{array}{l}\mathrm{CC}_{50} \\
(\mu \mathrm{M})\end{array}$ & $\mathrm{SI}^{\mathrm{c}}$ & \multicolumn{2}{|c|}{$\begin{array}{l}\mathrm{Cl}_{\text {int }} \\
(\mu \mathrm{L} / \mathrm{min} / \mathrm{mg})\end{array}$} & \\
\hline 17 & $\mathrm{CH}$ & - & $\mathrm{CH}$ & $\mathrm{H}$ & 0.296 & $>64$ & $>64$ & $>242$ & 15.3 & 216 & 3.15 \\
\hline 18 & $\mathrm{CH}$ & - & $\mathrm{CH}$ & $4-\mathrm{F}$ & 0.530 & $>64$ & $>64$ & $>120$ & 42.5 & 272 & 3.36 \\
\hline 19 & $\mathrm{CH}$ & - & $\mathrm{CH}$ & $3-\mathrm{F}$ & 0.224 & $>45$ & $>64$ & $>286$ & 25.3 & 207 & 3.36 \\
\hline 20 & $\mathrm{CH}$ & - & $\mathrm{CH}$ & $4-\mathrm{Cl}$ & 1.105 & $>55$ & $>62$ & $>74$ & 30.0 & 43.8 & 3.82 \\
\hline 21 & $\mathrm{CH}$ & - & $\mathrm{CH}$ & $3-\mathrm{Cl}$ & 0.396 & $>22$ & $>64$ & $>161$ & 30.8 & 63.5 & 3.82 \\
\hline 22 & $\mathrm{CH}$ & - & $\mathrm{CH}$ & $4-\mathrm{CN}$ & 2.862 & $>64$ & $>64$ & $>22$ & 25.3 & 80.8 & 3.03 \\
\hline 23 & $\mathrm{CH}$ & $\mathrm{O}$ & $\mathrm{CH}$ & $\mathrm{H}$ & 0.614 & $>40$ & $>64$ & $>109$ & 27.3 & 98.5 & 2.55 \\
\hline 24 & $\mathrm{CH}$ & $\mathrm{O}$ & $\mathrm{CH}$ & $4-\mathrm{CN}$ & 0.853 & $>64$ & $>63$ & $>74$ & 14.7 & 30.8 & 2.43 \\
\hline 25 & $\mathrm{CH}$ & $\mathrm{O}$ & $\mathrm{N}$ & $\mathrm{H}$ & 2.884 & $>64$ & $>63$ & $>21$ & $<11.9$ & 67.3 & 1.94 \\
\hline 26 & $\mathrm{~N}$ & - & $\mathrm{CH}$ & $4-\mathrm{F}$ & 2.370 & $>57$ & $>64$ & $>44$ & 30.8 & 46.5 & 2.78 \\
\hline 14 & - & - & - & - & 0.450 & $>64$ & $>64$ & $>142$ & 184 & 434 & 2.99 \\
\hline Miltefosine & - & - & - & - & 7.26 & 33.1 & 24.7 & 3.26 & n.d. & n.d. & 3.73 \\
\hline
\end{tabular}


${ }^{\mathrm{a}}$ Geometric-mean value of at least two independent tests in PMM. ${ }^{\mathrm{b}}$ Geometric-mean value of at least two independent tests in human fetal lung fibroblasts. ${ }^{\mathrm{c}}$ Selectivity index representing the ratio of $\mathrm{CC}_{50} / \mathrm{IC}_{50}$; data are presented as the geometric-mean value of ratios calculated using separate data from at least two independent tests. n.d., not determined.

Examples 20-26 combined good antileishmanial activity (and SI) with the desired improvement in HamLM stability and provided a number of options to evaluate this series in a hamster in vivo model of VL. Consequently, hamsters infected with L. infantum were treated with oral doses of a representative example (26) at $50 \mathrm{mg} / \mathrm{kg}$ b.i.d. for 5 days. Treatment with $\mathbf{2 6}$ resulted in $92.7 \%$ and $95 \%$ reduction in parasite burden in liver and spleen, respectively, without any obvious signs of toxicity. For comparison, when dosed orally at $40 \mathrm{mg} / \mathrm{kg}$ q.d. for 5 days, miltefosine showed 97.8\% (liver) and 99.6\% (spleen) reduction in parasite burden. Pharmacokinetic studies in hamsters with a single oral dose of $50 \mathrm{mg} / \mathrm{kg}$ demonstrated that $\mathbf{2 6}$ rapidly achieved good levels of exposure $\left(\mathrm{T}_{\max }=1.33 \mathrm{~h}, \mathrm{C}_{\max }=5,680 \mathrm{ng} / \mathrm{mL}, \mathrm{AUC}_{0-24 \mathrm{~h}}=25,376 \mathrm{~h} * \mathrm{ng} / \mathrm{mL}, \mathrm{t}_{1 / 2}=4.2 \mathrm{~h}\right)$. Consequently, these data illustrate that compounds (e.g. 26) from this novel series are able to successfully treat VL infection in an in vivo setting.

\section{CONCLUSION}

We have identified two subsets of active compounds developed from a single HTS hit (4). Early hit-expansion activities identified potent amides (7-10) that seem to require a 4-substituent on the pyrazole ring for good activity against intracellular L. infantum amastigotes. Unfortunately, these compounds also have poor metabolic stability in hamster liver microsomes, which precluded their evaluation in our hamster model of VL. In contrast, the subsequent design of urea analogues (e.g. 14, 17-26) provided potent activity against intracellular L. infantum amastigotes without the need for a pyrazole-4-substituent, combined with evidence of much-improved 
metabolic stability in hamster liver microsomes. Furthermore, this novel series of pyrazole ureas has potent antileishmanial activity against both L. infantum and L. donovani, the two species of Leishmania parasites that cause VL in humans. Examples from the series (e.g. 26) demonstrate high levels of in vivo efficacy in a hamster model of VL, representing a positive in vivo proof of concept. Furthermore, compounds from the series already meet a number of the published criteria for the selection of a clinical drug candidate for the oral treatment of VL. ${ }^{3,36}$ Additional efforts are ongoing to optimize the series (e.g. physicochemical properties, pharmacokinetics and solubility) and will be described in future publications.

\section{EXPERIMENTAL SECTION}

\section{Biology.}

Compounds and reagents. For in vitro assays, compound stock solutions were prepared in $100 \%$ DMSO at $20 \mathrm{mM}$. Compounds were serially pre-diluted (2-fold or 4-fold) in DMSO followed by a further (intermediate) dilution in demineralized water to assure a final in-test DMSO concentration of $<1 \%$. For in vivo efficacy studies, compound $\mathbf{2 6}$ was formulated in $4.5 \%(\mathrm{w} / \mathrm{v})$ methylcellulose (viscosity $=15 \mathrm{cps})$ and $5 \%(\mathrm{v} / \mathrm{v})$ Tween-80 in water at $25 \mathrm{mg} / \mathrm{mL}$. Miltefosine was formulated in water at $20 \mathrm{mg} / \mathrm{mL}$.

Cell cultures. Primary peritoneal mouse macrophages (PMM) were collected two days after peritoneal stimulation with a $2 \%$ potato starch suspension. $\mathrm{MRC}_{\mathrm{SV} 2}$ cells (diploid human embryonic lung fibroblasts) were cultured in minimal essential medium (MEM) containing Earle's salts, supplemented with L-glutamine, $\mathrm{NaHCO}_{3}$ and $5 \%$ inactivated foetal calf serum. All cultures and assays were conducted at $37^{\circ} \mathrm{C}$ under an atmosphere of $5 \% \mathrm{CO}_{2}$. 
Parasites. L. infantum (MHOM/MA/67/ITMAP263) and L. donovani (MHOM/ET/67/L82) were maintained in the golden (Syrian) hamster (Mesocricetus auratus). Ex vivo amastigotes were collected from the spleen of an infected donor hamster using two centrifugation purification steps: $230 \mathrm{~g}$ for $10 \mathrm{~min}$, keeping the supernatant layer, and 4,100g for $30 \mathrm{~min}$, keeping the pellet. The spleen parasite burden was assessed using the Stauber technique. ${ }^{40}$ For the in vitro assays, the inoculum was prepared in RPMI-1640 medium, supplemented with $200 \mathrm{mM}$ L-glutamine, $16.5 \mathrm{mM} \mathrm{NaHCO}_{3}$ and $5 \%$ inactivated foetal calf serum. For the in vivo model, an infection inoculum containing $2 \times 10^{7}$ amastigotes $/ 100 \mu \mathrm{L}$ was prepared in phosphate buffered saline (PBS).

Animals. Female golden hamsters for the in vivo model of visceral leishmaniasis were purchased from Janvier, France (body weight 80-100 g). This study using laboratory rodents was carried out in strict accordance to all mandatory guidelines (EU directives, including the Revised Directive 2010/63/EU on the protection of Animals used for Scientific Purposes that came into force on $01 / 01 / 2013$, and the declaration of Helsinki in its latest version) and was approved by the ethical committee of the University of Antwerp, Belgium (UA-ECD 2011-74). Female golden hamsters for the pharmacokinetic study were purchased from Vital River, Beijing, China. This study was conducted following institutional review and in accordance with institutional and national guidelines at $\mathrm{WuXi}$ AppTec (the Institutional Animal Care and Use Committee (IACUC)).

In vitro axenic $L$. donovani amastigote assay. The assay was performed as previously reported. $^{41}$ 
In vitro intramacrophage $L$. infantum amastigote assay. The assay was performed in sterile 96-well microtiter plates, each well containing $10 \mu \mathrm{L}$ of the compound dilution and $190 \mu \mathrm{L}$ of the PMM/amastigote inoculum $\left(3 \times 10^{4}\right.$ cells $/ 4.5 \times 10^{5}$ parasites per well $)$. Parasite multiplication was compared to untreated infected controls (100\% growth) and uninfected controls ( $0 \%$ growth). After five-day incubation, total parasite burdens were microscopically assessed after staining the cells with a $10 \%$ Giemsa solution. The results were expressed as percentage reduction in parasite burden compared to untreated control wells. $\mathrm{IC}_{50}$ values were determined using an extended dose range (2-fold compound dilutions, 8-point concentration curve). Miltefosine was used as the reference drug. ${ }^{42}$ For selected compounds, this assay format was also run using the L. donovani inoculum.

In vitro MRC5 and PMM cytotoxicity assays. Assays were performed in sterile 96-well microtiter plates, each well containing $10 \mu \mathrm{L}$ of the compound dilution and $190 \mu \mathrm{L}$ of MRC $5_{\mathrm{SV} 2}$ or PMM inoculum $\left(3 \times 10^{4}\right.$ cells $\left./ \mathrm{mL}\right)$. Cell growth was compared to untreated controls $(100 \%$ growth) and assay-media controls ( $0 \%$ growth). After three-day incubation, cell viability was assessed fluorometrically by adding resazurin $(50 \mu \mathrm{L} /$ well of a stock solution in phosphate buffer $(50 \mu \mathrm{g} / \mathrm{mL}))$, incubating for four hours and measuring fluorescence $\left(\lambda_{\mathrm{ex}} 550 \mathrm{~nm}, \lambda_{\mathrm{em}} 590 \mathrm{~nm}\right)$. The results were expressed as percentage reduction in cell growth compared to untreated control wells. $\mathrm{IC}_{50}$ values were determined using an extended dose range (2-fold compound dilutions, 8point concentration curve) to a highest concentration of $64 \mu \mathrm{M}$. Tamoxifen was included as the reference drug.

In vivo hamster model of visceral leishmaniasis. Female golden hamsters were randomly allocated to experimental groups of six animals each, based on body weight. At the start of the 
experiment (Day 0), each animal was infected with L. infantum inoculum, delivered by intracardial injection. Six hamsters were assigned to the vehicle-treated, infected control group. Six hamsters were assigned per group (1 group/compound) for the evaluation of compound 26 and miltefosine. At Day 21 post-infection (21 dpi), all animals in each group were dosed orally for five consecutive days (21-25 dpi): compound 26 was dosed at $50 \mathrm{mg} / \mathrm{kg}$ b.i.d.; miltefosine was dosed at $40 \mathrm{mg} / \mathrm{kg}$ q.d. At Day 35 (ten days after the final oral dose), all animals were euthanized and autopsies were conducted. The study evaluated the following parameters:

1. Adverse effects: all animals were observed daily for the occurrence/presence of adverse effects.

2. Body weight: all animals were weighed twice per week to monitor general health.

3. Parasite burden: amastigote burdens in each target organ (liver, spleen and bone marrow) were determined at Day 35. The organs of individual animals were weighed (except bone marrow). Impression smears were stained with Giemsa for microscopic examination of the total amastigote burden, defined as the mean number of amastigotes per cell multiplied by the number of cells counted (minimum 500 nuclei); results were expressed as a percentage reduction in amastigote burden compared to vehicle-treated, infected control animals.

Chemistry. Unless otherwise indicated, all reactions were magnetically stirred under an inert atmosphere. All reagents, including solvents, were used as received. Anhydrous solvents were dried in-house by passing through activated alumina. Thin-layer chromatography was performed on glass-backed precoated silica gel 60 plates, and compounds were visualized using UV light or iodine. Silica gel column chromatography was performed using 200-300-mesh silica gel. 
Preparative HPLC was performed using Gilson-281 liquid handlers equipped with one of four columns, chosen from: 1) Phenomenex Synergi C18 $150 \times 30 \mathrm{~mm}, 4 \mu \mathrm{m}, 2)$ YMC-pack ODSAQ $150 \times 30$ mm, $5 \mu \mathrm{m}, 3)$ Agella Venusil ASB C18 $150 \times 21.2 \mathrm{~mm}, 5 \mu \mathrm{m}$, or 4) Boston Symmetrix C18 ODS-R $150 \times 30 \mathrm{~mm}, 5 \mu \mathrm{m}$; elution was performed with $0.225 \%$ (by volume) of formic acid in water (solvent A), and acetonitrile (solvent B); fractions containing product were lyophilized. NMR spectra were recorded on a Bruker AVANCE $400 \mathrm{MHz}$ spectrometer in the solvents specified. LCMS spectra were recorded on an Agilent 1200 or Shimadzu 2020 spectrometer equipped with electrospray ionization, quadruple MS detector and Chromolith Flash RP-18e $25 \times 2.0 \mathrm{~mm}$ column, eluting with $0.0375 \%$ (by volume) of TFA in water (solvent A), and $0.01875 \%$ (by volume) of TFA in acetonitrile (solvent B). Analytical HPLC were performed using a Shimadzu LC20AB machine and one of two columns, chosen from: 1) Xtimate C18 $2.1 \times 30 \mathrm{~mm}, 3 \mu \mathrm{m}$, or 2) CHROM-MATRIX Innovation C18 $2.1 \times 30 \mathrm{~mm}, 2.6$ $\mu \mathrm{m}$; elution was performed with $0.0375 \%$ (by volume) of TFA in water (solvent A), and $0.01875 \%$ (by volume) of TFA in acetonitrile (solvent B). Purity of final compounds was $\geq 96 \%$, as determined by HPLC. Unless otherwise stated, final compounds were isolated as amorphous solids without collection of melting point data.

4-Chloro-3-(pyridin-2-yl)-1H-pyrazol-5-amine (1). To a solution of 3-(pyridin-2-yl)-1Hpyrazol-5-amine $(1.6 \mathrm{~g}, 10.0 \mathrm{mmol})$ in DMF $(16 \mathrm{~mL})$ at $0{ }^{\circ} \mathrm{C}$ was added $\mathrm{NCS}(1.47 \mathrm{~g}, 11.0$ mmol) in portions. The mixture was then stirred at $0{ }^{\circ} \mathrm{C}$ for $0.5 \mathrm{~h}$. Saturated aqueous $\mathrm{NH}_{4} \mathrm{Cl}$ solution $(150 \mathrm{~mL})$ was then added and the resulting precipitate was collected by filtration and dried under vacuum to yield 1 as a grey solid (1.3 g, 67\%). ${ }^{1} \mathrm{H}$ NMR (400 MHz, DMSO- $\left.d_{6}\right): \delta$ $12.45(\mathrm{~m}, 1 \mathrm{H}), 8.63(\mathrm{~d}, J=4.8 \mathrm{~Hz}, 1 \mathrm{H}), 7.90(\mathrm{~s}, 2 \mathrm{H}), 7.36(\mathrm{~s}, 1 \mathrm{H}), 4.94(\mathrm{~m}, 2 \mathrm{H})$. 
2-Cyclopropyl-3-oxo-3-(pyridin-2-yl)propanenitrile (2). To a solution of 2cyclopropylacetonitrile $(5.6 \mathrm{~g}, 76.7 \mathrm{mmol})$ in dry THF $(70 \mathrm{~mL})$ at $-78^{\circ} \mathrm{C}$ was added LDA $(80.6$ mmol, $40.3 \mathrm{~mL})$ dropwise and the mixture stirred for $1 \mathrm{~h}$. A solution of methyl picolinate $(10 \mathrm{~g}$, $73.0 \mathrm{mmol})$ in dry THF $(30 \mathrm{~mL})$ was then added dropwise, maintaining the temperature below $-60{ }^{\circ} \mathrm{C}$. After addition, the mixture was warmed slowly to room temperature and stirred for $18 \mathrm{~h}$. The mixture was quenched with $10 \%$ citric acid $(150 \mathrm{~mL})$, extracted with ethyl acetate $(100 \mathrm{~mL}$ $\times 2$ ), dried over anhydrous $\mathrm{Na}_{2} \mathrm{SO}_{4}$ and concentrated under reduced pressure to give $\mathbf{2}$ as a yellow oil (14.8 g, crude). ${ }^{1} \mathrm{H}$ NMR (400 MHz, $\left.\mathrm{CDCl}_{3}\right): \delta 8.73(\mathrm{~m}, 1 \mathrm{H}), 8.17(\mathrm{td}, J=7.9,1.0 \mathrm{~Hz}$, 1H), $7.93(\mathrm{dt}, J=7.7,1.8 \mathrm{~Hz}, 1 \mathrm{H}), 7.58(\mathrm{ddd}, J=7.6,4.8,1.2 \mathrm{~Hz}, 1 \mathrm{H}), 4.92(\mathrm{~d}, J=7.9 \mathrm{~Hz}, 1 \mathrm{H})$, $1.48(\mathrm{~m}, 1 \mathrm{H}), 0.69(\mathrm{~m}, 4 \mathrm{H})$.

4-Cyclopropyl-3-(pyridin-2-yl)-1H-pyrazol-5-amine (3). To a solution of 2-cyclopropyl-3oxo-3-(pyridin-2-yl)propanenitrile (2) (14.8 g, $73.0 \mathrm{mmol})$ in ethanol $(200 \mathrm{~mL})$ was added hydrazine hydrate $(4.3 \mathrm{~mL}, 79.6 \mathrm{mmol})$ and the mixture stirred at reflux for $16 \mathrm{~h}$. The mixture was cooled to room temperature and concentrated under reduced pressure. The residue was washed with petroleum ether/ethyl acetate $(10 / 1,50 \mathrm{~mL})$ to give 3 as a yellow solid $(11.5 \mathrm{~g}$, crude). ${ }^{1} \mathrm{H}$ NMR (400 MHz, DMSO- $\left.d_{6}\right): \delta 11.86(\mathrm{~s}, 1 \mathrm{H}), 8.59(\mathrm{td}, J=4.6,1.3 \mathrm{~Hz}, 1 \mathrm{H}), 7.88(\mathrm{~m}$, 2H), $7.30(\mathrm{~m}, 1 \mathrm{H}), 4.38(\mathrm{~s}, 2 \mathrm{H}), 1.69(\mathrm{~m}, 1 \mathrm{H}), 0.86(\mathrm{~m}, 2 \mathrm{H}), 0.36(\mathrm{~m}, 2 \mathrm{H})$.

Method A: Amide formation (4-10). To a solution of the corresponding amine (1.0 equiv) in acetonitrile at room temperature was added dropwise a solution of the corresponding acyl chloride (1.0 equiv) in acetonitrile. The reaction mixture was then stirred at reflux for $16 \mathrm{~h}$. After cooling to room temperature, the mixture was concentrated under reduced pressure to give the crude product, which was purified by HPLC. 


\section{3-Isopropoxy- $N$-(3-(pyridin-2-yl)-1H-pyrazol-5-yl)-5-(pyrrolidine-1-carbonyl) benzamide}

(4). To a suspension of dimethyl 5-hydroxyisophthalate $(21.0 \mathrm{~g}, 0.1 \mathrm{~mol})$ and anhydrous

potassium carbonate solution $(27.6 \mathrm{~g}, 0.2 \mathrm{~mol})$ in DMF $(100 \mathrm{~mL})$ at room temperature was added 2-bromopropane $(25.5 \mathrm{~g}, 0.15 \mathrm{~mol})$ and the mixture stirred at $80{ }^{\circ} \mathrm{C}$ for $16 \mathrm{~h}$. After cooling to room temperature, the mixture was diluted with water $(250 \mathrm{~mL})$ and extracted with ethyl acetate $(150 \mathrm{~mL} \times 2)$. The combined organic extracts were washed with brine $(100 \mathrm{~mL} \times 3)$, dried over anhydrous $\mathrm{Na}_{2} \mathrm{SO}_{4}$ and concentrated under reduced pressure to give dimethyl 5isopropoxyisophthalate as a white solid (25.0 g, crude). LC-MS (ESI) $m / z=253.1[\mathrm{M}+\mathrm{H}]^{+}, t=$ $1.250 \mathrm{~min}$.

To a solution of dimethyl 5-isopropoxyisophthalate $(20.0 \mathrm{~g}, 79.4 \mathrm{mmol})$ in methanol (400 mL) was added aqueous $\mathrm{NaOH}$ solution $(71 \mathrm{~mL}, 1 \mathrm{M}, 71 \mathrm{mmol})$ and the mixture stirred at $60{ }^{\circ} \mathrm{C}$ for $16 \mathrm{~h}$. The methanol was removed under reduced pressure and the residue diluted with water (150 $\mathrm{mL})$. The aqueous phase was adjusted to $\mathrm{pH} 6$ and extracted twice with ethyl acetate $(100 \mathrm{~mL})$. The combined organic extracts were washed with brine $(100 \mathrm{~mL})$, dried over anhydrous $\mathrm{Na}_{2} \mathrm{SO}_{4}$ and concentrated under reduced pressure to give 3-isopropoxy-5-(methoxycarbonyl)benzoic acid as a white solid (14.0 g, 74\%). LC-MS (ESI) $m / z=239.1[\mathrm{M}+\mathrm{H}]^{+}, t=1.010 \mathrm{~min} .{ }^{1} \mathrm{H}$ NMR $(400$ MHz, DMSO- $\left.d_{6}\right): \delta 8.05(\mathrm{t}, J=1.2 \mathrm{~Hz}, 1 \mathrm{H}), 7.63(\mathrm{~m}, 2 \mathrm{H}), 4.74(\mathrm{~m}, 1 \mathrm{H}), 3.87(\mathrm{~s}, 1 \mathrm{H}), 1.29(\mathrm{~d}, J$ $=6.0 \mathrm{~Hz}, 6 \mathrm{H})$.

To a solution of 3-isopropoxy-5-(methoxycarbonyl)benzoic acid (14.0 g, $58.8 \mathrm{mmol})$ in DMF $(140 \mathrm{~mL})$ was added HATU $(27.0 \mathrm{~g}, 71.0 \mathrm{mmol})$, triethylamine $(16.4 \mathrm{~mL}, 117.6 \mathrm{mmol})$ and pyrrolidine $(5.0 \mathrm{~g}, 70 \mathrm{mmol})$. The mixture was stirred at room temperature for $16 \mathrm{~h}$ then partitioned between ethyl acetate $(200 \mathrm{~mL})$ and water $(200 \mathrm{~mL})$. The aqueous phase was 
separated and extracted with further ethyl acetate $(200 \mathrm{~mL})$. The combined organic extracts were washed with saturated aqueous $\mathrm{NH}_{4} \mathrm{Cl}$ solution $(200 \mathrm{~mL})$ and brine $(200 \mathrm{~mL})$, dried over anhydrous $\mathrm{Na}_{2} \mathrm{SO}_{4}$ and concentrated under reduced pressure to give methyl 3-isopropoxy-5(pyrrolidine-1-carbonyl)benzoate as a white solid (16.5 g, 96\%). LC-MS (ESI) $m / z=292.2[\mathrm{M}+$ $\mathrm{H}]^{+}, t=1.020 \mathrm{~min}$.

To a solution of methyl 3-isopropoxy-5-(pyrrolidine-1-carbonyl)benzoate (16.5 g, $56.7 \mathrm{mmol})$ in methanol $(200 \mathrm{~mL})$ was added aqueous $\mathrm{NaOH}$ solution $(56.7 \mathrm{~mL}, 2 \mathrm{M}, 113.4 \mathrm{mmol})$ and the mixture stirred at room temperature for $16 \mathrm{~h}$. The solvent was removed under reduced pressure and the residue diluted with water $(150 \mathrm{~mL})$. The aqueous phase was adjusted to $\mathrm{pH} 5$ with aqueous $2 \mathrm{M} \mathrm{HCl}$ solution and extracted twice with ethyl acetate $(100 \mathrm{~mL})$. The combined organic layers were dried over anhydrous $\mathrm{Na}_{2} \mathrm{SO}_{4}$ and concentrated under reduced pressure to give 3-isopropoxy-5-(pyrrolidine-1-carbonyl)benzoic acid as a white solid (13.5 g, 86\%). LC$\operatorname{MS}(\mathrm{ESI}) m / z=278.1[\mathrm{M}+\mathrm{H}]^{+}, t=0.932 \mathrm{~min} .{ }^{1} \mathrm{H}$ NMR $\left(400 \mathrm{MHz}, \mathrm{DMSO}-d_{6}\right): \delta 7.55(\mathrm{~s}, 1 \mathrm{H})$, $7.44(\mathrm{~d}, J=0.8 \mathrm{~Hz}, 1 \mathrm{H}), 7.24(\mathrm{~s}, 1 \mathrm{H}), 4.71(\mathrm{~m}, 1 \mathrm{H}), 3.46(\mathrm{t}, J=6.0 \mathrm{~Hz}, 4 \mathrm{H}), 3.87(\mathrm{~s}, 1 \mathrm{H}), 1.84$ $(\mathrm{m}, 4 \mathrm{H}), 1.28(\mathrm{~d}, J=6.0 \mathrm{~Hz}, 6 \mathrm{H})$.

A solution of 3-isopropoxy-5-(pyrrolidine-1-carbonyl)benzoic acid (800 mg, $2.9 \mathrm{mmol})$ in thionyl chloride $(10 \mathrm{~mL})$ was stirred at reflux for $2 \mathrm{~h}$. The mixture was cooled to room temperature and concentrated under reduced pressure. The residue was diluted with toluene (10 $\mathrm{mL}$ ) and re-concentrated under reduced pressure to give 3-isopropoxy-5-(pyrrolidine-1carbonyl)benzoyl chloride as a white solid (860 mg, crude).

The title compound was synthesized according to Method A using 3-(pyridin-2-yl)-1H-pyrazol5-amine (462 mg, $2.9 \mathrm{mmol}$ ) and 3-isopropoxy-5-(pyrrolidine-1-carbonyl)benzoyl chloride (860 
$\mathrm{mg}, 2.9 \mathrm{mmol})$ in acetonitrile $(40 \mathrm{~mL})$, to yield 4 as a white solid (705 mg, 47\%). HPLC: 99\% pure. LC-MS (ESI) $m / z=420.2[\mathrm{M}+\mathrm{H}]^{+}, t=0.850 \mathrm{~min} .{ }^{1} \mathrm{H}$ NMR $\left(400 \mathrm{MHz}, \mathrm{DMSO}-d_{6}\right): \delta$ $13.20(\mathrm{~m}, 1 \mathrm{H}), 11.00(\mathrm{~m}, 1 \mathrm{H}), 8.63(\mathrm{~d}, J=3.6 \mathrm{~Hz}, 1 \mathrm{H}), 7.88(\mathrm{~m}, 2 \mathrm{H}), 7.66(\mathrm{~m}, 2 \mathrm{H}), 7.36(\mathrm{~s}, 1 \mathrm{H})$, $7.24(\mathrm{~s}, 1 \mathrm{H}), 7.17(\mathrm{~s}, 1 \mathrm{H}), 4.78(\mathrm{~m}, 1 \mathrm{H}), 3.48(\mathrm{t}, J=6.4 \mathrm{~Hz}, 2 \mathrm{H}), 3.40(\mathrm{t}, J=6.4 \mathrm{~Hz}, 2 \mathrm{H}), 1.86$ (m, 4H), $1.29(\mathrm{~m}, 6 \mathrm{H})$.

4-Chloro- $N$-(3-(pyridin-2-yl)-1H-pyrazol-5-yl)benzamide (5). The title compound was synthesized according to Method A using 3-(pyridin-2-yl)-1H-pyrazol-5-amine (100 mg, 0.63 mmol) and 4-chlorobenzoyl chloride (109 mg, $0.63 \mathrm{mmol})$ in acetonitrile $(10 \mathrm{~mL})$, to yield $\mathbf{5}$ as a white solid (76 mg, 41\%). HPLC: 99\% pure. MS (ESI) $m / z=299[\mathrm{M}+\mathrm{H}]^{+} .{ }^{1} \mathrm{H}$ NMR (400 MHz, DMSO-d $\left.d_{6}\right): \delta 11.06(\mathrm{~s}, 1 \mathrm{H}), 8.64(\mathrm{~d}, J=4.4 \mathrm{~Hz}, 1 \mathrm{H}), 8.04(\mathrm{~d}, J=8.8 \mathrm{~Hz}, 2 \mathrm{H}), 7.94(\mathrm{~m}, 2 \mathrm{H})$, $7.59(\mathrm{~d}, J=8.4 \mathrm{~Hz}, 2 \mathrm{H}), 7.40(\mathrm{~m}, 1 \mathrm{H}), 7.17(\mathrm{~s}, 1 \mathrm{H})$.

4-Methoxy-N-(3-(pyridin-2-yl)-1H-pyrazol-5-yl)benzamide (6). The title compound was synthesized according to Method A using 3-(pyridin-2-yl)-1H-pyrazol-5-amine (850 mg, 5.3 $\mathrm{mmol}$ ) and 4-methoxybenzoyl chloride $(895 \mathrm{mg}, 5.3 \mathrm{mmol})$ in acetonitrile $(100 \mathrm{~mL})$, to yield 6 as a white solid (1.04 g, 67\%). HPLC: 99\% pure. MS (ESI) $m / z=295[\mathrm{M}+\mathrm{H}]^{+} .{ }^{1} \mathrm{H}$ NMR (400 MHz, DMSO-d $\left.)_{6}\right): \delta 13.15(\mathrm{~s}, 1 \mathrm{H}), 10.75(\mathrm{~s}, 1 \mathrm{H}), 8.63(\mathrm{~d}, J=3.6 \mathrm{~Hz}, 1 \mathrm{H}), 8.04(\mathrm{~d}, J=8.4 \mathrm{~Hz}$, 2H), $7.88(\mathrm{~m}, 2 \mathrm{H}), 7.35(\mathrm{~s}, 1 \mathrm{H}), 7.24(\mathrm{~s}, 1 \mathrm{H}), 7.04(\mathrm{~d}, J=8.2 \mathrm{~Hz}, 2 \mathrm{H}), 3.84(\mathrm{~s}, 3 \mathrm{H})$.

\author{
N-(4-Cyclopropyl-3-(pyridin-2-yl)-1H-pyrazol-5-yl)-4-methoxybenzamide (7). The title \\ compound was synthesized according to Method A using 4-cyclopropyl-3-(pyridin-2-yl)-1H- \\ pyrazol-5-amine (3) (300 mg, $1.5 \mathrm{mmol})$ and 4-methoxybenzoyl chloride (255 $\mathrm{mg}, 1.5 \mathrm{mmol})$ in \\ acetonitrile $(20 \mathrm{~mL})$, to yield 7 as a white solid (80.7 mg, 16\%). HPLC: 98\% pure. MS (ESI) $\mathrm{m} / \mathrm{z}$ \\ $=335[\mathrm{M}+\mathrm{H}]^{+} .{ }^{1} \mathrm{H}$ NMR $\left(400 \mathrm{MHz}, \mathrm{DMSO}-d_{6}\right): \delta 13.07(\mathrm{~m}, 1 \mathrm{H}), 9.92(\mathrm{~s}, 1 \mathrm{H}), 8.67(\mathrm{~d}, J=4.8$
}


$\mathrm{Hz}, 1 \mathrm{H}), 8.00(\mathrm{~m}, 4 \mathrm{H}), 7.39(\mathrm{~m}, 1 \mathrm{H}), 7.07(\mathrm{~m}, 2 \mathrm{H}), 3.84(\mathrm{~s}, 3 \mathrm{H}), 1.82(\mathrm{~m}, 1 \mathrm{H}), 0.75(\mathrm{~m}, 2 \mathrm{H})$, $0.40(\mathrm{~m}, 2 \mathrm{H})$.

$N$-(4-Cyclopropyl-3-(pyridin-2-yl)-1 H-pyrazol-5-yl)-2-methoxybenzamide (8). The title compound was synthesized according to Method A using 4-cyclopropyl-3-(pyridin-2-yl)-1Hpyrazol-5-amine (3) (200 mg, $1.0 \mathrm{mmol})$ and 2-methoxybenzoyl chloride (170 $\mathrm{mg}, 1.0 \mathrm{mmol})$ in acetonitrile (15 mL), to yield 8 as a white solid (121.5 mg, 36\%). HPLC: 99\% pure. MS (ESI) $m / z=335[\mathrm{M}+\mathrm{H}]^{+} .{ }^{1} \mathrm{H}$ NMR $\left(400 \mathrm{MHz}, \mathrm{DMSO}-d_{6}\right): \delta 9.77(\mathrm{~s}, 1 \mathrm{H}), 8.65(\mathrm{~d}, J=4.8 \mathrm{~Hz}, 1 \mathrm{H})$, $7.95(\mathrm{~m}, 2 \mathrm{H}), 7.83(\mathrm{~m}, 1 \mathrm{H}), 7.54(\mathrm{~m}, 1 \mathrm{H}), 7.37(\mathrm{~m}, 1 \mathrm{H}), 7.22(\mathrm{~m}, 1 \mathrm{H}), 7.09(\mathrm{~m}, 1 \mathrm{H}), 3.96(\mathrm{~s}$, $3 \mathrm{H}), 1.88(\mathrm{~m}, 1 \mathrm{H}), 0.82(\mathrm{~m}, 2 \mathrm{H}), 0.46(\mathrm{~m}, 2 \mathrm{H})$.

$N$-(4-Cyclopropyl-3-(pyridin-2-yl)-1H-pyrazol-5-yl)-2-fluorobenzamide (9). The title compound was synthesized according to Method A using 4-cyclopropyl-3-(pyridin-2-yl)-1Hpyrazol-5-amine (3) (100 mg, $0.5 \mathrm{mmol})$ and 2-fluorobenzoyl chloride (79 $\mathrm{mg}, 0.5 \mathrm{mmol})$ in acetonitrile (10 mL), to yield 9 as a white solid (40.4 mg, 25\%). HPLC: $96 \%$ pure. MS (ESI) $\mathrm{m} / z$ $=323[\mathrm{M}+\mathrm{H}]^{+} .{ }^{1} \mathrm{H}$ NMR $\left(400 \mathrm{MHz}, \mathrm{DMSO}-d_{6}\right): \delta 13.10(\mathrm{~s}, 1 \mathrm{H}), 10.04(\mathrm{~s}, 1 \mathrm{H}), 8.67(\mathrm{~d}, J=4.0$ $\mathrm{Hz}, 1 \mathrm{H}), 7.97(\mathrm{~m}, 2 \mathrm{H}), 7.71(\mathrm{dd}, J=8.0,8.0 \mathrm{~Hz}, 1 \mathrm{H}), 7.56(\mathrm{~m}, 1 \mathrm{H}), 7.37(\mathrm{~m}, 3 \mathrm{H}), 1.85(\mathrm{~s}, 1 \mathrm{H})$, $0.82(\mathrm{~d}, J=7.2 \mathrm{~Hz}, 2 \mathrm{H}), 0.44(\mathrm{~d}, J=4.4 \mathrm{~Hz}, 2 \mathrm{H})$.

\section{2,6-Dichloro- $N$-(4-cyclopropyl-3-(pyridin-2-yl)-1H-pyrazol-5-yl)benzamide (10). The title} compound was synthesized according to Method A using 4-cyclopropyl-3-(pyridin-2-yl)-1Hpyrazol-5-amine (3) (200 mg, $1.0 \mathrm{mmol})$ and 2,6-dichlorobenzoyl chloride (273 mg, $1.3 \mathrm{mmol})$ in acetonitrile $(15 \mathrm{~mL})$, to yield $\mathbf{1 0}$ as a white solid (23.1 mg, 6\%). HPLC: 98\% pure. MS (ESI) $m / z=373[\mathrm{M}+\mathrm{H}]^{+} .{ }^{1} \mathrm{H}$ NMR $\left(400 \mathrm{MHz}, \mathrm{DMSO}-d_{6}\right): \delta 13.08(\mathrm{~m}, 1 \mathrm{H}), 10.33(\mathrm{~s}, 1 \mathrm{H}), 8.67(\mathrm{~d}, J=$ 
$4.8 \mathrm{~Hz}, 1 \mathrm{H}), 7.96(\mathrm{~m}, 2 \mathrm{H}), 7.57(\mathrm{~m}, 2 \mathrm{H}), 7.50(\mathrm{~m}, 1 \mathrm{H}), 7.48(\mathrm{~m}, 1 \mathrm{H}), 1.86(\mathrm{~s}, 1 \mathrm{H}), 0.86(\mathrm{~m}, 2 \mathrm{H})$, $0.44(\mathrm{~m}, 2 \mathrm{H})$.

Method B: Phenyl carbamate formation (11-13). To a solution of the corresponding amine (1.0 equiv) in pyridine at $0^{\circ} \mathrm{C}$ was added phenyl chloroformate (1.0 equiv) dropwise over a period of $0.5 \mathrm{~h}$. The reaction mixture was then stirred at room temperature for $12 \mathrm{~h}$. The mixture was quenched with water, filtered and the resulting solid washed with water to give the product, which was dried under vacuum.

Phenyl (3-(pyridin-2-yl)-1H-pyrazol-5-yl)carbamate (11). The title compound was synthesized according to Method B using 3-(pyridin-2-yl)-1H-pyrazol-5-amine (25.0 g, 0.156 mol) and phenyl chloroformate $(24.4 \mathrm{~g}, 0.156 \mathrm{~mol})$ in pyridine $(250 \mathrm{~mL})$, to yield $\mathbf{1 1}$ as a grey solid (30 g, 69\%). ${ }^{1} \mathrm{H}$ NMR (400 MHz, DMSO-d $)$ ): $\delta 13.09$ (br s, $\left.1 \mathrm{H}\right), 10.61(\mathrm{~m}, 1 \mathrm{H}), 8.61(\mathrm{~m}$, 1H), $7.86(\mathrm{~m}, 2 \mathrm{H}), 7.44(\mathrm{~m}, 2 \mathrm{H}), 7.35(\mathrm{~m}, 1 \mathrm{H}), 7.27(\mathrm{~m}, 1 \mathrm{H}), 7.22(\mathrm{~d}, J=7.8 \mathrm{~Hz}, 2 \mathrm{H}), 6.89(\mathrm{~m}$, $1 \mathrm{H})$.

Phenyl (4-chloro-3-(pyridin-2-yl)-1H-pyrazol-5-yl)carbamate (12). The title compound was synthesized according to Method B using 4-chloro-3-(pyridin-2-yl)-1H-pyrazol-5-amine (1) (200 $\mathrm{mg}, 1.0 \mathrm{mmol})$ and phenyl chloroformate $(160 \mathrm{mg}, 1.0 \mathrm{mmol})$ in pyridine $(5 \mathrm{~mL})$, to yield 12 as a brown oil (300 mg, crude) that was used directly in the next step (to make 15).

Phenyl (4-cyclopropyl-3-(pyridin-2-yl)-1H-pyrazol-5-yl)carbamate (13). The title compound was synthesized according to Method B using 4-cyclopropyl-3-(pyridin-2-yl)-1H-pyrazol-5amine (3) (200 mg, $1.0 \mathrm{mmol})$ and phenyl chloroformate (160 mg, $1.0 \mathrm{mmol})$ in pyridine $(5 \mathrm{~mL})$, to yield 13 as a brown oil (300 mg, crude) that was used directly in the next step (to make 14). 
Method C: Urea Formation (14-26). A mixture of the corresponding phenyl carbamate (1.0 equiv), the corresponding amine (1.0 equiv) and triethylamine (2.0 equiv) in chloroform was stirred at reflux for $16 \mathrm{~h}$. After cooling to room temperature, the mixture was concentrated under reduced pressure to give the crude product, which was purified by HPLC.

1-(3-Chlorophenyl)methyl-3-(3-(pyridin-2-yl)-1H-pyrazol-5-yl)urea (14). The title compound was synthesized according to Method C using phenyl (3-(pyridin-2-yl)-1H-pyrazol-5yl)carbamate (11) and 3-chlorobenzylamine, to yield 14 (4 mg). HPLC: 100\% pure. MS (ESI) $m / z=328[\mathrm{M}+\mathrm{H}]^{+}, 350[\mathrm{M}+\mathrm{Na}]^{+} .{ }^{1} \mathrm{H}$ NMR $\left(400 \mathrm{MHz}, \mathrm{DMSO}-d_{6}\right): \delta 12.83$ (br s, $\left.1 \mathrm{H}\right), 8.97$ (br $\mathrm{s}, 1 \mathrm{H}), 8.59(\mathrm{~m}, 1 \mathrm{H}), 7.82(\mathrm{~m}, 2 \mathrm{H}), 7.32(\mathrm{~m}, 6 \mathrm{H}), 6.71$ (br s, 1H), $4.36(\mathrm{~d}, 2 \mathrm{H})$.

1-Benzyl-3-(4-chloro-3-(pyridin-2-yl)-1H-pyrazol-5-yl)urea (15). The title compound was synthesized according to Method C using phenyl (4-chloro-3-(pyridin-2-yl)-1H-pyrazol-5yl)carbamate (12) (300 mg, $0.95 \mathrm{mmol})$ and benzylamine $(153 \mathrm{mg}, 1.43 \mathrm{mmol})$ in chloroform (10 mL), to yield 15 as a white solid (129 mg, 41\%). HPLC: 100\% pure. MS (ESI) $m / z=328$ [M $+\mathrm{H}]^{+} .{ }^{1} \mathrm{H}$ NMR $\left(400 \mathrm{MHz}, \mathrm{DMSO}-d_{6}\right): \delta 13.38(\mathrm{~m}, 1 \mathrm{H}), 8.67(\mathrm{~m}, 2 \mathrm{H}), 7.95(\mathrm{~s}, 2 \mathrm{H}), 7.41(\mathrm{~m}$, 1H), $7.34(\mathrm{~m}, 4 \mathrm{H}), 7.26(\mathrm{~m}, 2 \mathrm{H}), 4.34(\mathrm{~d}, J=6.0 \mathrm{~Hz}, 2 \mathrm{H})$.

1-Benzyl-3-(4-cyclopropyl-3-(pyridin-2-yl)-1H-pyrazol-5-yl)urea (16). The title compound was synthesized according to Method C using phenyl (4-cyclopropyl-3-(pyridin-2-yl)-1Hpyrazol-5-yl)carbamate $(\mathbf{1 3})(150 \mathrm{mg}, 0.47 \mathrm{mmol})$ and benzylamine $(76 \mathrm{mg}, 0.70 \mathrm{mmol})$ in chloroform (5 mL), to yield 16 as a light yellow solid (45.8 mg, 29\%). HPLC: 97\% pure. MS (ESI) $m / z=334[\mathrm{M}+\mathrm{H}]^{+} .{ }^{1} \mathrm{H}$ NMR $\left(400 \mathrm{MHz}, \mathrm{DMSO}-d_{6}\right): \delta 12.80(\mathrm{~m}, 1 \mathrm{H}), 8.63(\mathrm{~d}, J=4.8 \mathrm{~Hz}$, $1 \mathrm{H}), 8.01(\mathrm{~m}, 3 \mathrm{H}), 7.35(\mathrm{~m}, 7 \mathrm{H}), 4.35(\mathrm{~d}, J=5.6 \mathrm{~Hz}, 2 \mathrm{H}), 1.77(\mathrm{~m}, 1 \mathrm{H}), 0.84(\mathrm{~m}, 2 \mathrm{H}), 0.35(\mathrm{~m}$, $2 \mathrm{H})$. 
4-Phenyl- $N$-(3-(pyridin-2-yl)-1H-pyrazol-5-yl)piperidine-1-carboxamide (17). The title compound was synthesized according to Method C using phenyl (3-(pyridin-2-yl)-1H-pyrazol-5yl)carbamate (11) (3.0 g, $10.7 \mathrm{mmol})$, 4-phenylpiperidine (1.9 g, $11.8 \mathrm{mmol}$ ) and triethylamine (3.7 $\mathrm{mL}, 26.8 \mathrm{mmol})$ in chloroform $(80 \mathrm{~mL})$ to yield the crude product, which was precipitated from ethyl acetate $(100 \mathrm{~mL})$, filtered and recrystallized from DMSO $(20 \mathrm{~mL})$ to yield 17 as a white solid (1.09 g, 29\%). Mp $=237^{\circ} \mathrm{C}$. HPLC: $99 \%$ pure. MS (ESI) $m / z=348[\mathrm{M}+\mathrm{H}]^{+} .{ }^{1} \mathrm{H}$ NMR (400 MHz, $\left.\mathrm{CDCl}_{3}\right): \delta 12.66(\mathrm{~m}, 1 \mathrm{H}), 8.61(\mathrm{~d}, J=4.8 \mathrm{~Hz}, 1 \mathrm{H}), 7.74(\mathrm{~m}, 1 \mathrm{H}), 7.68(\mathrm{~m}, 2 \mathrm{H})$, $7.50(\mathrm{~s}, 1 \mathrm{H}), 7.32(\mathrm{~m}, 2 \mathrm{H}), 7.27(\mathrm{~m}, 4 \mathrm{H}), 7.09(\mathrm{~m}, 1 \mathrm{H}), 4.24(\mathrm{~d}, J=13.6 \mathrm{~Hz}, 2 \mathrm{H}), 3.00(\mathrm{td}, J=$ 12.8, 2.4 Hz, 2H), $2.72(\mathrm{~m}, 1 \mathrm{H}), 1.91(\mathrm{~d}, J=11.2 \mathrm{~Hz}, 2 \mathrm{H}), 1.72(\mathrm{~m}, 2 \mathrm{H})$.

4-(4-Fluorophenyl)- $N$-(3-(pyridin-2-yl)-1H-pyrazol-5-yl)piperidine-1-carboxamide (18). The title compound was synthesized according to Method C using phenyl (3-(pyridin-2-yl)-1Hpyrazol-5-yl)carbamate (11) and 4-(4-fluorophenyl)piperidine, to yield 18 (4 mg). HPLC: 100\% pure. MS (ESI) $m / z=366[\mathrm{M}+\mathrm{H}]^{+}, 388[\mathrm{M}+\mathrm{Na}]^{+} .{ }^{1} \mathrm{H}$ NMR $\left(400 \mathrm{MHz}, \mathrm{CDCl}_{3}\right): \delta 10.77(\mathrm{br} \mathrm{s}$, $1 \mathrm{H}), 8.60(\mathrm{~m}, 1 \mathrm{H}), 7.77(\mathrm{t}, 1 \mathrm{H}), 7.67(\mathrm{~d}, 1 \mathrm{H}), 7.26(\mathrm{~m}, 4 \mathrm{H}), 7.10(\mathrm{~m}, 3 \mathrm{H}), 4.25(\mathrm{~d}, 2 \mathrm{H}), 3.03(\mathrm{t}$, 2H), $2.75(\mathrm{~m}, 1 \mathrm{H}), 1.93(\mathrm{~d}, 2 \mathrm{H}), 1.71(\mathrm{~m}, 2 \mathrm{H})$.

4-(3-Fluorophenyl)- $N$-(3-(pyridin-2-yl)-1H-pyrazol-5-yl)piperidine-1-carboxamide (19). The title compound was synthesized according to Method C using phenyl (3-(pyridin-2-yl)-1Hpyrazol-5-yl)carbamate (11) and 4-(3-fluorophenyl)piperidine, to yield 19 (4.5 mg). HPLC: $100 \%$ pure. MS (ESI) $m / z=366[\mathrm{M}+\mathrm{H}]^{+}, 388[\mathrm{M}+\mathrm{Na}]^{+} .{ }^{1} \mathrm{H} \mathrm{NMR}\left(400 \mathrm{MHz}, \mathrm{CDCl}_{3}\right): \delta 11.16$ (br s, $1 \mathrm{H}), 8.62(\mathrm{~d}, J=4.4 \mathrm{~Hz}, 1 \mathrm{H}), 7.77(\mathrm{t}, J=7.6 \mathrm{~Hz}, 1 \mathrm{H}), 7.68(\mathrm{~d}, J=8.0 \mathrm{~Hz}, 1 \mathrm{H}), 7.45$ (s, 1H), $7.26(\mathrm{~m}, 2 \mathrm{H}), 7.09(\mathrm{~s}, 1 \mathrm{H}), 7.00(\mathrm{~d}, J=7.6 \mathrm{~Hz}, 1 \mathrm{H}), 6.93(\mathrm{~m}, 2 \mathrm{H}), 4.26(\mathrm{~d}, J=12.8 \mathrm{~Hz}$, 2H), $3.02(\mathrm{t}, J=12.4 \mathrm{~Hz}, 2 \mathrm{H}), 2.75(\mathrm{~m}, 1 \mathrm{H}), 1.94(\mathrm{~d}, J=12.8 \mathrm{~Hz}, 2 \mathrm{H}), 1.70(\mathrm{~m}, 2 \mathrm{H})$. 


\section{4-(4-Chlorophenyl)- $N$-(3-(pyridin-2-yl)-1H-pyrazol-5-yl)piperidine-1-carboxamide (20).}

The title compound was synthesized according to Method C using phenyl (3-(pyridin-2-yl)-1Hpyrazol-5-yl)carbamate (11) (2.6 g, 9.28mmol), 4-(4-chlorophenyl)piperidine (2.2 g, $9.52 \mathrm{mmol})$ and triethylamine $(3.2 \mathrm{~mL}, 23.2 \mathrm{mmol})$ in chloroform $(70 \mathrm{~mL})$, to yield the crude product, which was precipitated from ethyl acetate $(100 \mathrm{~mL})$, filtered and recrystallized from DMSO $(25 \mathrm{~mL})$ to yield 20 as a white solid (0.998 g, 28\%). $\mathrm{Mp}=231^{\circ} \mathrm{C}$. HPLC: $98 \%$ pure. MS (ESI) $\mathrm{m} / z=382$ $[\mathrm{M}+\mathrm{H}]^{+} .{ }^{1} \mathrm{H}$ NMR $\left(400 \mathrm{MHz}, \mathrm{DMSO}-d_{6, t}=80{ }^{\circ} \mathrm{C}\right): \delta 12.54(\mathrm{~m}, 1 \mathrm{H}), 8.73(\mathrm{~m}, 1 \mathrm{H}), 8.58(\mathrm{~d}, J=$ $4.0 \mathrm{~Hz}, 1 \mathrm{H}), 7.82(\mathrm{~m}, 2 \mathrm{H}), 7.30(\mathrm{~m}, 5 \mathrm{H}), 6.87(\mathrm{~m}, 1 \mathrm{H}), 4.27(\mathrm{~d}, J=13.2 \mathrm{~Hz}, 2 \mathrm{H}), 2.91(\mathrm{t}, J=$ $12.0 \mathrm{~Hz}, 2 \mathrm{H}), 2.81(\mathrm{~m}, 1 \mathrm{H}), 1.82(\mathrm{~d}, J=12.0 \mathrm{~Hz}, 2 \mathrm{H}), 1.59(\mathrm{~m}, 2 \mathrm{H})$.

\section{4-(3-Chlorophenyl)- $N$-(3-(pyridin-2-yl)-1H-pyrazol-5-yl)piperidine-1-carboxamide (21).}

The title compound was synthesized according to Method C using phenyl (3-(pyridin-2-yl)- $1 H$ pyrazol-5-yl)carbamate (11) and 4-(3-chlorophenyl)piperidine, to yield 21 (3 mg). HPLC: 98.8\% pure. MS (ESI) $m / z=382[\mathrm{M}+\mathrm{H}]^{+}, 404[\mathrm{M}+\mathrm{Na}]^{+} .{ }^{1} \mathrm{H}$ NMR $\left(400 \mathrm{MHz}, \mathrm{CDCl}_{3}\right): \delta 10.78($ br s, 1H), $8.60(\mathrm{~m}, 1 \mathrm{H}), 7.77(\mathrm{~m}, 1 \mathrm{H}), 7.67(\mathrm{~m}, 1 \mathrm{H}), 7.24(\mathrm{~m}, 5 \mathrm{H}), 7.10(\mathrm{~m}, 2 \mathrm{H}), 4.27(\mathrm{~m}, 2 \mathrm{H}), 3.03$ $(\mathrm{m}, 2 \mathrm{H}), 2.75(\mathrm{~m}, 1 \mathrm{H}), 1.95(\mathrm{~m}, 2 \mathrm{H}), 1.72(\mathrm{~m}, 2 \mathrm{H})$.

4-(4-Cyanophenyl)-N-(3-(pyridin-2-yl)-1H-pyrazol-5-yl)piperidine-1-carboxamide (22). The title compound was synthesized according to Method C using phenyl (3-(pyridin-2-yl)-1Hpyrazol-5-yl)carbamate (11) and 4-(4-piperidinyl)benzonitrile, to yield 22 (3.6 mg). HPLC: 98.7\% pure. MS (ESI) $m / z=373[\mathrm{M}+\mathrm{H}]^{+}, 395[\mathrm{M}+\mathrm{Na}]^{+} .{ }^{1} \mathrm{H} \mathrm{NMR}\left(400 \mathrm{MHz}, \mathrm{CDCl}_{3}\right): \delta$ $11.13($ br s, $1 \mathrm{H}), 8.60(\mathrm{~d}, J=4.0 \mathrm{~Hz}, 1 \mathrm{H}), 7.76(\mathrm{t}, J=7.6 \mathrm{~Hz}, 1 \mathrm{H}), 7.66(\mathrm{~d}, J=8.0 \mathrm{~Hz}, 1 \mathrm{H}), 7.61$ $(\mathrm{d}, J=8.0 \mathrm{~Hz}, 2 \mathrm{H}), 7.45(\mathrm{~s}, 1 \mathrm{H}), 7.31(\mathrm{~d}, J=8.4 \mathrm{~Hz}, 2 \mathrm{H}), 7.25(\mathrm{~m}, 1 \mathrm{H}), 7.08(\mathrm{~s}, 1 \mathrm{H}), 4.26(\mathrm{~d}, J=$ $13.6 \mathrm{~Hz}, 2 \mathrm{H}), 3.00(\mathrm{t}, J=12.4 \mathrm{~Hz}, 2 \mathrm{H}), 2.79(\mathrm{~m}, 1 \mathrm{H}), 1.91(\mathrm{~d}, J=12.4 \mathrm{~Hz}, 2 \mathrm{H}), 1.71(\mathrm{~m}, 2 \mathrm{H})$. 
4-Phenoxy- $N$-(3-(pyridin-2-yl)-1H-pyrazol-5-yl)piperidine-1-carboxamide (23). The title compound was synthesized according to Method C using phenyl (3-(pyridin-2-yl)-1H-pyrazol-5yl)carbamate (11) and 4-(phenoxy)-piperidine, to yield 23 (393 mg). HPLC: 100\% pure. MS (ESI) $m / z=364[\mathrm{M}+\mathrm{H}]^{+}, 386[\mathrm{M}+\mathrm{Na}]^{+} .{ }^{1} \mathrm{H} \mathrm{NMR}\left(400 \mathrm{MHz}, \mathrm{CDCl}_{3}\right): \delta 11.19$ (br s, $\left.1 \mathrm{H}\right), 8.60$ $(\mathrm{d}, J=4.4 \mathrm{~Hz}, 1 \mathrm{H}), 7.75(\mathrm{~m}, 1 \mathrm{H}), 7.67(\mathrm{~m}, 1 \mathrm{H}), 7.42(\mathrm{~s}, 1 \mathrm{H}), 7.28(\mathrm{~m}, 3 \mathrm{H}), 7.08$ (br s, 1H), 6.97 $(\mathrm{t}, J=7.2 \mathrm{~Hz}, 1 \mathrm{H}), 6.93(\mathrm{~d}, J=8.0 \mathrm{~Hz}, 2 \mathrm{H}), 4.56(\mathrm{~m}, 1 \mathrm{H}), 3.73(\mathrm{~m}, 2 \mathrm{H}), 3.52(\mathrm{~m}, 2 \mathrm{H}), 1.99(\mathrm{~m}$, 2H), $1.89(\mathrm{~m}, 2 \mathrm{H})$.

4-(4-Cyanophenoxy)- $N$-(3-(pyridin-2-yl)-1H-pyrazol-5-yl)piperidine-1-carboxamide (24). The title compound was synthesized according to Method C using phenyl (3-(pyridin-2-yl)- $1 H$ pyrazol-5-yl)carbamate (11) (3.2 g, 11.4 mmol), 4-(piperidin-4-yloxy)benzonitrile (2.6 g, 12.9 $\mathrm{mmol})$ and triethylamine $(3.96 \mathrm{~mL}, 28.6 \mathrm{mmol})$ in chloroform $(80 \mathrm{~mL})$, to yield the crude product, which was purified by silica gel chromatography (dichloromethane/methanol, 50:1 to 10:1) and recrystallized from acetonitrile/methanol $(4: 1,25 \mathrm{~mL})$ to yield 24 as a white solid (1.05 g, 24\%). Mp $=223{ }^{\circ} \mathrm{C} . \mathrm{HPLC}: 98 \%$ pure. MS (ESI) $m / z=389[\mathrm{M}+\mathrm{H}]^{+} .{ }^{1} \mathrm{H}$ NMR $(400$ $\left.\mathrm{MHz}, \mathrm{CDCl}_{3}\right): \delta 11.37(\mathrm{~m}, 1 \mathrm{H}), 8.62(\mathrm{~d}, J=5.2 \mathrm{~Hz}, 1 \mathrm{H}), 7.76(\mathrm{ddd}, J=8.0,8.0,1.6,1 \mathrm{H}), 7.60$ (m, 4H), $7.25(\mathrm{~d}, J=6.0 \mathrm{~Hz}, 1 \mathrm{H}), 7.08(\mathrm{~m}, 1 \mathrm{H}), 6.94(\mathrm{~d}, J=8.8 \mathrm{~Hz}, 2 \mathrm{H}), 4.61(\mathrm{td}, J=6.40,2.8$ $\mathrm{Hz}, 1 \mathrm{H}), 3.70(\mathrm{~m}, 2 \mathrm{H}), 3.51(\mathrm{~m}, 2 \mathrm{H}), 2.01(\mathrm{~m}, 2 \mathrm{H}), 1.85(\mathrm{td}, J=6.4,4.0 \mathrm{~Hz}, 2 \mathrm{H})$.

\section{N-(3-(Pyridin-2-yl)-1H-pyrazol-5-yl)-4-(pyridin-2-yloxy)piperidine-1-carboxamide (25).}

The title compound was synthesized according to Method C using phenyl (3-(pyridin-2-yl)-1Hpyrazol-5-yl)carbamate (11) (2.8 g, $10.0 \mathrm{mmol})$, 2-(piperidin-4-yloxy)pyridine hydrochloride $(2.5 \mathrm{~g}, 11.7 \mathrm{mmol})$ and triethylamine $(3.47 \mathrm{~mL}, 25.0 \mathrm{mmol})$ in chloroform $(80 \mathrm{~mL})$ to yield the crude product, which was purified by silica gel chromatography (dichloromethane/methanol, 50:1 to 10:1) and recrystallized from acetonitrile/methanol $(4: 1,25 \mathrm{~mL})$ to yield $\mathbf{2 5}$ as a white 
solid $(1.46 \mathrm{~g}, 40 \%) . \mathrm{Mp}=216{ }^{\circ} \mathrm{C} . \mathrm{HPLC}: 98 \%$ pure. MS (ESI) $m / z=365[\mathrm{M}+\mathrm{H}]^{+} .{ }^{1} \mathrm{H}$ NMR $\left(400 \mathrm{MHz}, \mathrm{CDCl}_{3}\right): \delta 11.07(\mathrm{~m}, 1 \mathrm{H}), 8.60(\mathrm{~d}, J=4.8 \mathrm{~Hz}, 1 \mathrm{H}), 8.14(\mathrm{~d}, J=4.8 \mathrm{~Hz}, 1 \mathrm{H}), 7.76(\mathrm{~m}$, 1H), $7.67(\mathrm{~m}, 1 \mathrm{H}), 7.58(\mathrm{t}, J=8.0 \mathrm{~Hz}, 1 \mathrm{H}), 7.37(\mathrm{~s}, 1 \mathrm{H}), 7.21-7.26(\mathrm{~m}, 1 \mathrm{H}), 7.09(\mathrm{~m}, 1 \mathrm{H}), 6.87$ $(\mathrm{t}, J=6.0 \mathrm{~Hz}, 1 \mathrm{H}), 6.73(\mathrm{~d}, J=8.4 \mathrm{~Hz}, 1 \mathrm{H}), 5.31(\mathrm{~m}, 1 \mathrm{H}), 3.79(\mathrm{~m}, 2 \mathrm{H}), 3.47(\mathrm{~m}, 2 \mathrm{H}), 2.08(\mathrm{~m}$, 2H), $1.86(\mathrm{~m}, 2 \mathrm{H})$.

\title{
4-(4-Fluorophenyl)- $N$-(3-(pyridin-2-yl)-1H-pyrazol-5-yl)piperazine-1-carboxamide (26).
}

The title compound was synthesized according to Method C using phenyl (3-(pyridin-2-yl)-1Hpyrazol-5-yl)carbamate (11) and 1-(4-fluorophenyl)-piperazine, to yield 26 (842 mg). HPLC: $100 \%$ pure. MS (ESI) m/z = $389[\mathrm{M}+\mathrm{Na}]^{+} .{ }^{1} \mathrm{H}$ NMR (400 MHz, DMSO- $\left.d_{6}\right): \delta 12.77$ (br s, $1 \mathrm{H}$ ), 9.24 (br s, 1H), $8.60(\mathrm{~m}, 1 \mathrm{H}), 7.78(\mathrm{~m}, 2 \mathrm{H}), 7.30(\mathrm{~m}, 1 \mathrm{H}), 7.05(\mathrm{~m}, 4 \mathrm{H}), 6.82(\mathrm{br} \mathrm{s}, 1 \mathrm{H}), 3.62(\mathrm{~m}$, 4H), $3.10(\mathrm{~m}, 4 \mathrm{H})$.

\section{AUTHOR INFORMATION}

\section{Corresponding Author}

*Charles E. Mowbray. E-mail: cmowbray@dndi.org. Phone: + 41 (0)22 9069220.

\section{Present Addresses}

${ }^{\Delta}$ Mojozi Consulting (Pty) Ltd., 88 Tenth Ave, Sydenham, Johannesburg, 2092, Gauteng, SA.

\author{
Author Contributions \\ ${ }^{\boldsymbol{\Delta}}$ Paul A. Glossop prepared this manuscript on behalf of all the authors. All authors have given \\ approval to the final version of the manuscript.
}

\section{Funding Sources}


The authors gratefully acknowledge financial support for this work from United Kingdom Department for International Development (DFID), Dutch Ministry of Foreign Affairs (DGIS), Swiss Agency for Development and Cooperation (SDC), Bill \& Melinda Gates Foundation, German Federal Ministry of Education and Research (BMBF) through KfW, and Médecins Sans Frontières (Doctors without Borders).

\title{
ACKNOWLEDGMENT
}

The DND $i$ thanks Pfizer Ltd for generously providing access to the original library of compounds used for the HTS, and also for ongoing advice and support from staff in Pfizer Worldwide Medicinal Chemistry. The DND $i$ also thank the staff of SCYNEXIS Inc., WuXi AppTech, iThemba Pharmaceuticals and LMPH for their individual practical contributions to this work. In addition, we thank Robert T. Jacobs and Jason Speake of SCYNEXIS Inc. for their contributions to the initial hit confirmation and early expansion of the amide series.

\author{
ABBREVIATIONS \\ $\mathrm{CC}_{50}$, half-maximum cytotoxic concentration; $\mathrm{CL}$, cutaneous leishmaniasis; $\mathrm{Cl}_{\text {int }}$, intrinsic \\ clearance; DNDi, Drugs for Neglected Diseases initiative; HLM, human liver microsomes; \\ HamLM, hamster liver microsomes; LAB, liposomal amphotericin B; L. donovani, Leishmania \\ donovani; L. infantum, Leishmania infantum; MRC5, human fetal lung fibroblasts; NTD, \\ neglected tropical disease; PM, paromomycin; PMM, primary mouse macrophages; SI, \\ selectivity index; SSG, sodium stibogluconate; TPP, target product profile; VL, visceral \\ leishmaniasis.
}

\section{REFERENCES}


(1) WHO. Control of the Leishmaniases. World Health Organ. Tech. Rep. Ser. 2010, 949, ixiii, $1-186$.

(2) Hussain, H.; Al-Harrasi, A.; Al-Rawahi, A.; Green, I. R.; Gibbons, S. Fruitful Decade for Antileishmanial Compounds from 2002 to Late 2011. Chem. Rev. 2014, 114, 10369-10428.

(3) Freitas-Junior, L. H.; Chatelain, E.; Kim, H. A.; Siqueira-Neto, J. L. Visceral Leishmaniasis Treatment: What Do We Have, What Do We Need and How to Deliver It? Int. J. Parasitol. Drugs Drug Resist. 2012, 2, 11-19.

(4) WHO. Research Priorities for Chagas Disease, Human African Trypanosomiasis and Leishmaniasis. World Health Organ. Tech. Rep. Ser. 2012, 975, i-xii, 1-100.

(5) WHO. Leishmaniasis. World Health Organ. Fact Sheet 2014, 375.

(6) Wyllie, S.; Patterson, S.; Stojanovski, L.; Simeons, F. R. C.; Norval, S.; Kime, R.; Read, K. D.; Fairlamb, A. H. The Anti-Trypanosome Drug Fexinidazole Shows Potential for Treating Visceral Leishmaniasis. Sci. Transl. Med. 2012, 4, 119re1.

(7) DNDi. Phase II Proof of Concept Trial to Determine Efficacy of Fexinidazole in Visceral Leishmaniasis Patients in Sudan. http://clinicaltrials.gov/show/NCT01980199 (accessed Oct 3, 2014).

(8) Gupta, S.; Yardley, V.; Vishwakarma, P.; Shivahare, R.; Sharma, B.; Launay, D.; Martin, D.; Puri, S. K. Nitroimidazo-Oxazole Compound DNDI-VL-2098: An Orally Effective Preclinical Drug Candidate for the Treatment of Visceral Leishmaniasis. J. Antimicrob. Chemother. 2015, 70, 518-527. 
(9) Mukkavilli, R.; Pinjari, J.; Patel, B.; Sengottuvelan, S.; Mondal, S.; Gadekar, A.; Verma, M.; Patel, J.; Pothuri, L.; Chandrashekar, G.; Koiram, P.; Harisudhan, T.; Moinuddin, A.; Launay, D.; Vachharajani, N.; Ramanathan, V.; Martin, D. In Vitro Metabolism, Disposition, Preclinical Pharmacokinetics and Prediction of Human Pharmacokinetics of DNDI-VL-2098, a Potential Oral Treatment for Visceral Leishmaniasis. Eur. J. Pharm. Sci. 2014, 65, 147-155.

(10) Patterson, S.; Wyllie, S. Nitro Drugs for the Treatment of Trypanosomatid Diseases: Past, Present, and Future Prospects. Trends Parasitol. 2014, 30, 289-298.

(11) DNDi. R\&D Portfolio: Patient Needs-Driven Collaborative R\&D Model for Neglected Diseases. http://www.dndi.org/pdf-portfolio/ (accessed Oct 3, 2014).

(12) Gopinath, V. S.; Pinjari, J.; Dere, R. T.; Verma, A.; Vishwakarma, P.; Shivahare, R.; Moger, M.; Kumar Goud, P. S.; Ramanathan, V.; Bose, P.; Rao, M. V. S.; Gupta, S.; Puri, S. K.; Launay, D.; Martin, D. Design, Synthesis and Biological Evaluation of 2-Substituted Quinolines as Potential Antileishmanial Agents. Eur. J. Med. Chem. 2013, 69, 527-536.

(13) Gopinath, V. S.; Rao, M.; Shivahare, R.; Vishwakarma, P.; Ghose, S.; Pradhan, A.; Hindupur, R.; Sarma, K. Das; Gupta, S.; Puri, S. K.; Launay, D.; Martin, D. Design, Synthesis, ADME Characterization and Antileishmanial Evaluation of Novel Substituted Quinoline Analogs. Bioorg. Med. Chem. Lett. 2014, 24, 2046-2052.

(14) Bhuniya, D.; Mukkavilli, R.; Shivahare, R.; Launay, D.; Dere, R. T.; Deshpande, A.; Verma, A.; Vishwakarma, P.; Moger, M.; Pradhan, A.; Pati, H.; Gopinath, V. S.; Gupta, S.; Puri, S. K.; Martin, D. Aminothiazoles: Hit to Lead Development to Identify Antileishmanial Agents. Eur. J. Med. Chem. 2015, 102, 582-593. 
(15) Van Horn, K. S.; Zhu, X.; Pandharkar, T.; Yang, S.; Vesely, B.; Vanaerschot, M.; Dujardin, J.-C.; Rijal, S.; Kyle, D. E.; Wang, M. Z.; Werbovetz, K. A.; Manetsch, R. Antileishmanial Activity of a Series of N2,N4-Disubstituted Quinazoline-2,4-Diamines. J. Med. Chem. 2014, 57, 5141-5156.

(16) Zhu, X.; Van Horn, K. S.; Barber, M. M.; Yang, S.; Wang, M. Z.; Manetsch, R.; Werbovetz, K. A. SAR Refinement of Antileishmanial N(2),N(4)-Disubstituted Quinazoline-2,4Diamines. Bioorg. Med. Chem. 2015, 23, 5182-5189.

(17) Hutton, J. A.; Goncalves, V.; Brannigan, J. A.; Paape, D.; Wright, M. H.; Waugh, T. M.; Roberts, S. M.; Bell, A. S.; Wilkinson, A. J.; Smith, D. F.; Leatherbarrow, R. J.; Tate, E. W. Structure-Based Design of Potent and Selective Leishmania N-Myristoyltransferase Inhibitors. $J$. Med. Chem. 2014, 57, 8664-8670.

(18) Castera-Ducros, C.; Paloque, L.; Verhaeghe, P.; Casanova, M.; Cantelli, C.; Hutter, S.; Tanguy, F.; Laget, M.; Remusat, V.; Cohen, A.; Crozet, M. D.; Rathelot, P.; Azas, N.; Vanelle, P. Targeting the Human Parasite Leishmania Donovani: Discovery of a New Promising AntiInfectious Pharmacophore in 3-nitroimidazo[1,2-a]pyridine Series. Bioorg. Med. Chem. 2013, $21,7155-7164$.

(19) Galiana-Roselló, C.; Bilbao-Ramos, P.; Dea-Ayuela, M. A.; Rolón, M.; Vega, C.; BolásFernández, F.; García-España, E.; Alfonso, J.; Coronel, C.; González-Rosende, M. E. In Vitro and in Vivo Antileishmanial and Trypanocidal Studies of New N-Benzene- and NNaphthalenesulfonamide Derivatives. J. Med. Chem. 2013, 56, 8984-8998.

(20) Sobarzo-Sánchez, E.; Bilbao-Ramos, P.; Dea-Ayuela, M.; González-Díaz, H.; Yañez, M.; Uriarte, E.; Santana, L.; Martínez-Sernández, V.; Bolás-Fernández, F.; Ubeira, F. M. Synthetic 
Oxoisoaporphine Alkaloids: In Vitro, in Vivo and in Silico Assessment of Antileishmanial Activities. PLoS One 2013, 8, e77560.

(21) Reid, C. S.; Farahat, A. A.; Zhu, X.; Pandharkar, T.; Boykin, D. W.; Werbovetz, K. A. Antileishmanial Bis-Arylimidamides: DB766 Analogs Modified in the Linker Region and BisArylimidamide Structure-Activity Relationships. Bioorg. Med. Chem. Lett. 2012, 22, 68066810.

(22) Pinto, E. G.; Santos, I. O.; Schmidt, T. J.; Borborema, S. E. T.; Ferreira, V. F.; Rocha, D. R.; Tempone, A. G. Potential of 2-Hydroxy-3-Phenylsulfanylmethyl-[1,4]-Naphthoquinones against Leishmania (L.) Infantum: Biological Activity and Structure-Activity Relationships. PLoS One 2014, 9, e105127.

(23) Shivahare, R.; Korthikunta, V.; Chandasana, H.; Suthar, M. K.; Agnihotri, P.; Vishwakarma, P.; Chaitanya, T. K.; Kancharla, P.; Khaliq, T.; Gupta, S.; Bhatta, R. S.; Pratap, J. V.; Saxena, J. K.; Gupta, S.; Tadigoppula, N. Synthesis, Structure-Activity Relationships, and Biological Studies of Chromenochalcones as Potential Antileishmanial Agents. J. Med. Chem. 2014, 57, 3342-3357.

(24) Sharma, M.; Chauhan, K.; Shivahare, R.; Vishwakarma, P.; Suthar, M. K.; Sharma, A.; Gupta, S.; Saxena, J. K.; Lal, J.; Chandra, P.; Kumar, B.; Chauhan, P. M. S. Discovery of a New Class of Natural Product-Inspired Quinazolinone Hybrid as Potent Antileishmanial Agents. $J$. Med. Chem. 2013, 56, 4374-4392.

(25) Suryawanshi, S. N.; Kumar, S.; Shivahare, R.; Pandey, S.; Tiwari, A.; Gupta, S. Design, Synthesis and Biological Evaluation of Aryl Pyrimidine Derivatives as Potential Leishmanicidal Agents. Bioorg. Med. Chem. Lett. 2013, 23, 5235-5238. 
(26) Bonano, V. I.; Yokoyama-Yasunaka, J. K. U.; Miguel, D. C.; Jones, S. A.; Dodge, J. A.; Uliana, S. R. B. Discovery of Synthetic Leishmania Inhibitors by Screening of a 2Arylbenzothiophene Library. Chem. Biol. Drug Des. 2014, 83, 289-296.

(27) Morais, S. M. de; Vila-Nova, N. S.; Bevilaqua, C. M. L.; Rondon, F. C.; Lobo, C. H.; Moura, A. de A. A.; Sales, A. D.; Rodrigues, A. P. R.; Figuereido, J. R. de; Campello, C. C.; Wilson, M. E.; de Andrade, H. F. Thymol and Eugenol Derivatives as Potential Antileishmanial Agents. Bioorg. Med. Chem. 2014, 22, 6250-6255.

(28) Faria, J. V; dos Santos, M. S.; Bernardino, A. M. R.; Becker, K. M.; Machado, G. M. C.; Rodrigues, R. F.; Canto-Cavalheiro, M. M.; Leon, L. L. Synthesis and Activity of Novel Tetrazole Compounds and Their Pyrazole-4-Carbonitrile Precursors against Leishmania Spp. Bioorg. Med. Chem. Lett. 2013, 23, 6310-6312.

(29) Blagg, J. Structure-Activity Relationships for In Vitro and In Vivo Toxicity. Annu. Rep. Med. Chem. 2006, 41, 353-368.

(30) Dos Santos, M. S.; Oliveira, M. L. V; Bernardino, A. M. R.; de Léo, R. M.; Amaral, V. F.; de Carvalho, F. T.; Leon, L. L.; Canto-Cavalheiro, M. M. Synthesis and Antileishmanial Evaluation of 1-Aryl-4-(4,5-Dihydro-1H-Imidazol-2-yl)-1H-Pyrazole Derivatives. Bioorg. Med. Chem. Lett. 2011, 21, 7451-7454.

(31) Dos Santos Faiões, V.; Leon, L. L.; Canto-Cavalheiro, M. M.; Torres-Santos, E. C.; Bernardino, A. M. R.; Vegi, P. F.; dos Santos, M. S. Effectiveness of Novel 5-(5-Amino-1-Aryl1H-Pyrazol-4-yl)-1H-Tetrazole Derivatives against Promastigotes and Amastigotes of Leishmania Amazonensis. Chem. Biol. Drug Des. 2014, 83, 272-277. 
(32) Bernardino, A. M. R.; Gomes, A. O.; Charret, K. S.; Freitas, A. C. C.; Machado, G. M. C.; Canto-Cavalheiro, M. M.; Leon, L. L.; Amaral, V. F. Synthesis and Leishmanicidal Activities of 1-(4-X-Phenyl)-N'-[(4-Y-Phenyl)methylene]-1H-Pyrazole-4-Carbohydrazides. Eur. J. Med. Chem. 2006, 41, 80-87.

(33) Santos, M. S. dos; Gomes, A. O.; Bernardino, A. M. R.; Souza, M. C. de; Khan, M. A.; Brito, M. A. de; Castro, H. C.; Abreu, P. A.; Rodrigues, C. R.; Léo, R. M. M. de; Leon, L. L.; Canto-Cavalheiro, M. M. Synthesis and Antileishmanial Activity of New 1-Aryl-1H-Pyrazole-4Carboximidamides Derivatives. J. Braz. Chem. Soc. 2011, 22, 352-358.

(34) Borges, J. C.; Carvalho, A. V.; Bernardino, A. M. R.; Oliveira, C. D.; Pinheiro, L. C. S.; Marra, R. K. F.; Castro, H. C.; Wardell, S. M. S. V.; Wardell, J. L.; Amaral, V. F.; CantoCavalheiro, M. M.; Leon, L. L.; Genestra, M. Synthesis and in Vitro Evaluation of New Benzenesulfonamides as Antileishmanial Agents. J. Braz. Chem. Soc. 2014, 25, 980-986.

(35) Marra, R. K. F.; Bernardino, A. M. R.; Proux, T. A.; Charret, K. S.; Lira, M.-L. F.; Castro, H. C.; Souza, A. M. T.; Oliveira, C. D.; Borges, J. C.; Rodrigues, C. R.; CantoCavalheiro, M. M.; Leon, L. L.; Amaral, V. F. 4-(1H-Pyrazol-1-yl) Benzenesulfonamide Derivatives: Identifying New Active Antileishmanial Structures for Use against a Neglected Disease. Molecules 2012, 17, 12961-12973.

(36) DNDi. Leishmaniasis; Target Product Profile for VL. http://www.dndi.org/diseasesprojects/diseases/vl/tpp/tpp-vl.html (accessed Jan 22, 2015).

(37) Siqueira-Neto, J. L.; Moon, S.; Jang, J.; Yang, G.; Lee, C.; Moon, H. K.; Chatelain, E.; Genovesio, A.; Cechetto, J.; Freitas-Junior, L. H. An Image-Based High-Content Screening 
Assay for Compounds Targeting Intracellular Leishmania Donovani Amastigotes in Human Macrophages. PLoS Negl. Trop. Dis. 2012, 6, e1671.

(38) Gupta, S. Visceral Leishmaniasis: Experimental Models for Drug Discovery. Indian J. Med. Res. 2011, 133, 27-39.

(39) Ghose, A. K.; Viswanadhan, V. N.; Wendoloski, J. J. Prediction of Hydrophobic (Lipophilic) Properties of Small Organic Molecules Using Fragmental Methods: An Analysis of ALOGP and CLOGP Methods. J. Phys. Chem. A 1998, 102, 3762-3772.

(40) Stauber, L. A. Characterization of Strains of Leishmania Donovani. Exp. Parasitol. 1966, $18,1-11$.

(41) Mercer, L.; Bowling, T.; Perales, J.; Freeman, J.; Nguyen, T.; Bacchi, C.; Yarlett, N.; Don, R.; Jacobs, R.; Nare, B. 2,4-Diaminopyrimidines as Potent Inhibitors of Trypanosoma Brucei and Identification of Molecular Targets by a Chemical Proteomics Approach. PLoS Negl. Trop. Dis. 2011, 5, e956.

(42) Maes, L.; Vanden Berghe, D.; Germonprez, N.; Quirijnen, L.; Cos, P.; De Kimpe, N.; Van Puyvelde, L. In Vitro and in Vivo Activities of a Triterpenoid Saponin Extract (PX-6518) from the Plant Maesa Balansae against Visceral Leishmania Species. Antimicrob. Agents Chemother. 2004, 48, 130-136.

Table of Contents graphic. 


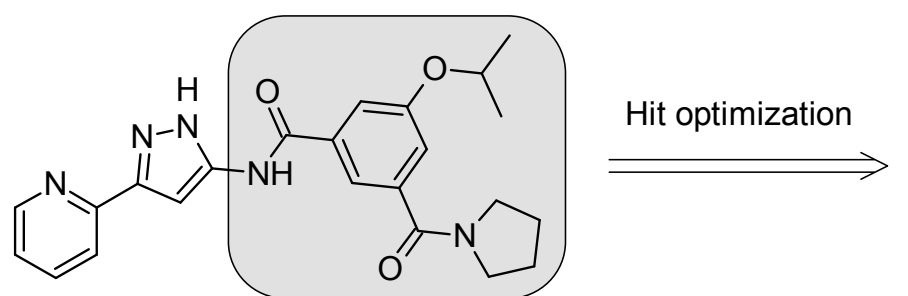

4, HTS hit

Leishmania donovani amastigotes in THP-1 cells: $\mathrm{IC}_{50}=10 \mu \mathrm{M}$

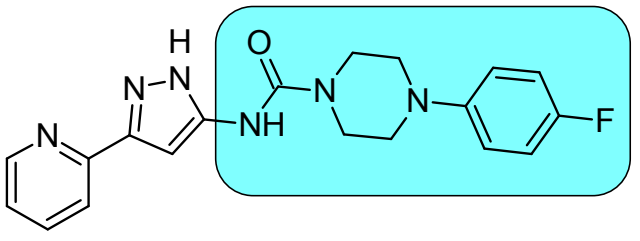

26, Early lead

Leishmania donovani amastigotes in PMM cells: $I_{50}=1.31 \mu \mathrm{M}$ Hamster model of Leishmania infantum visceral leishmaniasis: efficacy $>90 \%$ 